\title{
Stabilization Policy Ten Years After
}

WHEN the Brookings panel first met ten years ago, the U.S. government's managers of aggregate demand were cooling an economy suffering from an inflation 4 points higher than ten years before. The unemployment rate was 4.5 percent. Four years later, at the time of the panel's thirteenth meeting, the demand managers were cooling an economy suffering from an inflation 6 points higher still. The unemployment rate was 5 percent. As the panel meets today, the government's managers of aggregate demand are cooling an economy suffering from an inflation 7 points higher than ten years before. The unemployment rate is 7 percent and rising.

Higher inflation, higher unemployment-the relentless combination frustrated policymakers, forecasters, and theorists throughout the decade. The disarray in diagnosing stagflation and prescribing a cure makes any appraisal of the theory and practice of macroeconomic stabilization as of 1980 a foolhardy venture. The patent breakdown of consensus spares me the task of seeking and describing collective views. I will just give my own observations and confess my own puzzlements.

In one respect demand-management policies worked as intended in the 1970s. On each of the occasions I described at the beginning, the man-

I am grateful to my colleagues at Yale and to members of the Brookings panel for comments on the original version, to Ray C. Fair also for the use of his model reported in the paper, and especially to members of the panel for many discussions of substance and for painstaking guidance of the revision. Bret Bertolin and Kathleen K. Donahoo provided efficient statistical and editorial assistance. Laura Harrison and other Cowles Foundation staff miraculously produced the typescripts under deadline pressures of my own making. The work was in part supported by the National Science Foundation and the Cowles Foundation. 


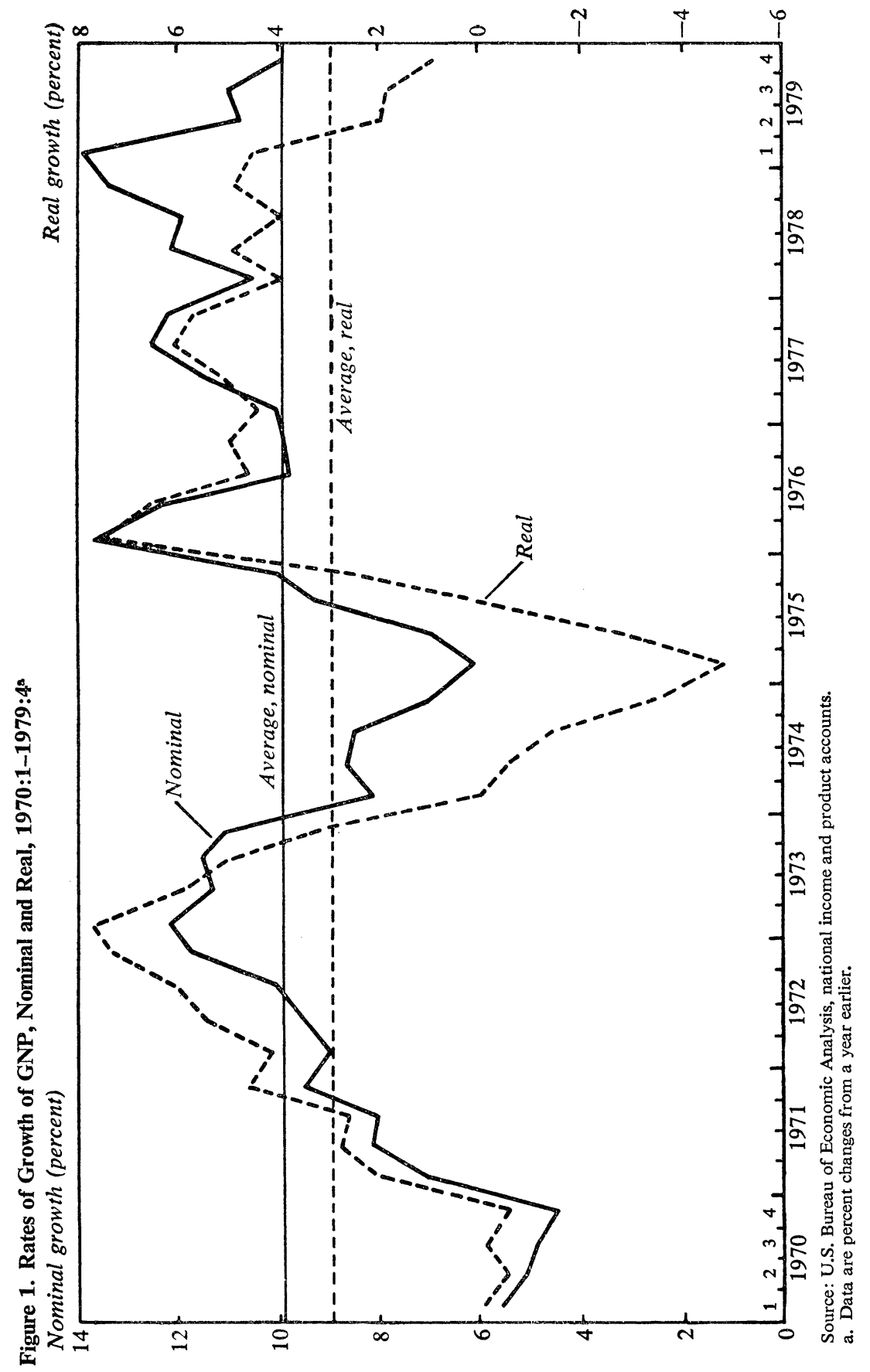


agers succeeded in cooling the economy. Thus the decade is distinguished by its three recessions, all deliberately induced by policy. Likewise the expansionary policies adopted to reverse the first two recessions, beginning in 1971 and 1975 respectively, promoted recoveries, and in 1977 the new Carter administration succeeded in sustaining and reinforcing the expansion. Figure 1 shows the changes of nominal and real GNP during the decade. The major turns in direction conformed to the desires and intentions of the managers of aggregate demand.

However, the expansions of 1973 and 1978-79 and the recessions of 1974-75 and 1980 were doubtless more than the managers bargained for. One reason was that when the patient did not respond promptly to moderate medication the impatient physicians multiplied the dosage. In June 1974 and again in March 1980 the Federal Reserve, frustrated in waiting for evidence of a downturn responding to previous restrictive measures and alarmed by continued bad news of inflation, sharply boosted nominal interest rates. On both occasions the cycle was already beyond its peak, and the final blows were overkill.

The conformity of real to nominal GNP movements depicted in figure 1 and the greater amplitude of the nominal series make a striking prima facie case that nominal demand fluctuations were calling the tune. The exceptions occurred during the autonomous commodity price shocks of 1974 and 1979.

Whatever difficulties there were in the management of nominal demand, the major disappointments came at the next stage. The inflationary components of the expansions, 1971-73 and 1975-79, were unexpectedly and distressingly large. The disinflationary consequence of the first contraction, 1969-71, was discouragingly small. Indeed, money wages "exploded" while unemployment was rising. Price inflation fell sharply at and after the trough of the second contraction. OPEC-1, decontrol, and food shortages had produced the double-digit inflationary bulge, and once the resulting price increases were absorbed or reversed overall inflation rates subsided quickly. But wage inflation stayed on a somewhat higher plateau, spelling price trouble especially when productivity growth later slowed to a halt. The disinflationary rewards of the 1980 recession remain to be seen.

U.S. stabilization policy in the 1970 s was complicated by important new developments in the world economy.

International constraints became even more compelling than they had 
been in the 1960s. Foreign trade was greater relative to GNP, and the growing size and efficiency of Eurocurrency institutions linked U.S. financial markets more tightly to those in other jurisdictions. In August 1971 the United States abrogated the Bretton Woods agreement, made the dollar inconvertible into gold, and forced other major countries to appreciate their currencies against the dollar. These steps led in 1973 to abandonment of pegged exchange rates in favor of "dirty" floating. But the new regime did not in the end fulfill the hope, long nurtured by economists, that floating would relax the international constraints on domestic policies.

The major economic events of the decade were the extraordinary changes in world supplies and prices of specific commodities. Their interaction with macroeconomic indicators and events confronted both policymakers and analysts with problems for which they were unprepared. In the United States in particular, analyses of inflation had habitually focused on the wage-price patterns of the "fixprice" sector. In the 1970s the "flexprice" sector, instead of being a passive and innocuous appendage, was a major source of macroeconomic shocks. Shortages and price increases in foodstuffs, metals, and other primary materials were the salient feature of the worldwide 1973 inflationary boom. Then, of course, OPEC and the energy crisis dominated the world economic scene for the rest of the decade, as they will likely continue to do for the foreseeable future. The cartel's price and supply are obviously not "flex" in the sense of being determined in competitive markets, but they are certainly detached from the familiar wage-price-production milieu of domestic industry.

These events have complicated the game and escalated the stakes, but the tormenting issues of strategy have remained essentially the same throughout the period since the Second World War. Can the instruments of demand management achieve both monetary stability and satisfactory real economic performance? If so, how? If not, what are the terms of feasible choices, and what criteria should guide them? If the macroeconomic instruments are inadequate for the goals, is it useful to supplement them with incomes policies temporarily or permanently?

I begin by describing what I call the consensus macroeconomic model, vintage 1970, of which the core was the augmented Phillips curve. A loose consensus on the framework for thinking about demand management left ample scope for differences about structural details and values of param- 
eters and for practical disagreements of diagnosis and prescription. I then review the failures of the consensus framework to prepare economists and our audiences for the macroeconomic surprises of the 1970s; I discuss both the damage to the framework and its repair. Some of the new problems arise from the revelation that the supply and demand blades of the macroeconomic scissors are not as disjointed as the earlier consensus framework found it convenient to assume. Consequently, this topic leads me naturally into a discussion of supply-side economics and policy recommendations.

As I implied at the beginning, an analysis of demand management can be approached in two stages. The first concerns the connections from policy instruments to dollar spending on goods and services. The second concerns the impact of nominal spending on prices and real output. I am not arguing for any separation theorem, only for some convenience of exposition. In 1980 the issues concerning the first stage seem secondary to those of the second stage. Nevertheless, I then take another look at the old monetarist debate, the conduct of monetary and fiscal policy, and the monetary-fiscal mix.

Finally, I return to the big analytical and policy issues of the second stage, concluding with some thoughts on where to go from here.

\section{The Consensus Macroeconomic Framework, Vintage 1970}

Ten years ago there was a broad consensus on the structure of the system that the managers of aggregate demand were trying to stabilize. The consensus pervaded the Brookings panel and was gradually becoming embodied in most macroeconometric models used for forecasting and policy analysis. It left plenty of room for disagreements about policy. They concerned the empirical magnitudes of some crucial structural parameters, the relative importance of nonpolicy demand shocks and policy variations themselves as sources of instability, the reliability and strength of stabilizing responses by private agents in decentralized markets, and the value weights attached to various dimensions of economic performance-inflation, unemployment, and output. The consensus on structure, within which these debates occurred, contained the following elements:

1. The nonagricultural business sector plays the central role in deter- 
mining the economy's rate of inflation. In this sector, prices are markedup labor costs, usually adjusted to normal operating rates and productivity trends. According to the standard "augmented Phillips curve" view, rates of price and wage increase depend partly on their recent trends, partly on expectations of their future movements, and partly on the tightness (demand relative to supply at prevailing wages and prices) of markets for products and labor.

2. Variations in aggregate monetary demand, whether the consequences of policies or of other events, affect the course of prices and output, and wages and employment, by altering the tightness of labor and product markets, and in no other way. As a corollary, at least to a first approximation any mix of fiscal and monetary policies that yields the same aggregate demand has the same impact on inflation and real activity. Changing the mix cannot appreciably alter the short-run trade-off between inflation and employment. The proportions of fiscal and monetary stimulus or restriction can and must be decided on other grounds.

3. The tightness of markets can be related to the utilization of productive resources, reported or adjusted unemployment rates, and capacityoperating rates. At any given utilization rates, real output grows at a steady pace (then estimated to be 3.5 to 4 percent a year), reflecting trends in supplies of labor and capital and in productivity. According to Okun's Law, in cyclical fluctuations each percentage point of unemployment corresponds to 3 percent of GNP, a bit less than one year's normal growth.

4. Inflation accelerates at high employment rates because tight markets systematically and repeatedly generate wage and price increases in addition to those already incorporated in expectations and historical patterns. At low utilization rates, inflation decelerates, but probably at an asymmetrically slow pace. At the Phelps-Friedman "natural rate of unemployment," the degrees of resource utilization and market tightness generate no net wage and price pressures up or down and are consistent with accustomed and expected paths, whether stable prices or any other inflation rate. ${ }^{1}$ The consensus view accepted the notion of a nonaccelerating inflation rate of unemployment (NAIRU) as a practical constraint

1. Milton Friedman, "The Role of Monetary Policy," American Economic Review, vol. 58 (March 1968), pp. 1-17; and Edmund S. Phelps, "Phillips Curves, Expectations of Inflation and Optimal Unemployment over Time," Economica, n.s., vol. 34 (August 1967), pp. 254-81. 
on policy, even though some of its adherents would not identify NAIRU as full, equilibrium, or optimum employment. ${ }^{2}$

5. On the instruments of demand management themselves, there was less consensus. The monetarist counterrevolution had provided debate over the efficacy of monetary and fiscal measures, the process of transmission of monetary policies to total spending, the proper indicators and targets of monetary policy, and the utility of active compensatory management.

\section{MONETARISM: THE TWO WAVES}

Monetarism has come in two waves, and I find it useful to distinguish their doctrines and policy implications, even though they have many commonalities and connections, both intellectual and personal. Monetarism1 was principally, in the words of its most influential protagonist, "the monetary theory of nominal income."3 This asserted the causal primacy of variations of money stock in fluctuations of aggregate dollar demand for goods and services. By the same token, it denied that pure fiscal policies, changes in overall expenditures and taxation that leave money stocks unaffected, have more than minor and transient effects on the path of nominal income. Likewise the doctrine attributed to instability of monetary supplies rather than to exogenous real shocks (that is, in capital productivity and thrift) responsibility for the major economic fluctuations of history. The major policy recommendation follows: keep money supply on a predictable stable path, without reference to recent or contemporaneous states of the economy or to the government budget.

By 1970 the debate triggered by these monetarist propositions had been raging for most of a decade-indeed, for much longer if disputes over the ancient quantity theory of money are counted. The 1960 s conflict had been fought with theoretical and statistical weapons in professional media, and it had spilled into the public and political arena. At meetings of the Brookings panel, I believe, the majority view still rejected the strong proposition of the monetary theory of nominal income and favored the more eclectic modern Keynesian paradigm that had

2. Terminology of this kind apparently originated in Franco Modigliani and Lucas Papademos, "Targets for Monetary Policy in the Coming Year," BPEA, 1: 1975, pp. 141-63.

3. Milton Friedman, "A Monetary Theory of Nominal Income," Journal of Political Economy, vol. 79 (March-April 1971), pp. 323-37. 
guided demand-management policies during the "new economics" years of the 1960s. According to this paradigm, monetary policies, fiscal policies, and nonpolicy shocks are all important determinants of aggregate demand. But by 1970 increasing attention was being paid, by macroeconomic analysts and model builders and by policymakers and central bankers, to measures of money supply, the "monetary aggregates." I comment below on this old debate. In 1980, however, it seems less fundamental than the challenge to the consensus view from the second wave of monetarism-Monetarism-2.

Keynesians and proponents of Monetarism- 1 could disagree about the determinants of monetary demand but agree, at least qualitatively, on the structure that in the short run converts demand into output and prices. In fact Milton Friedman's candidate for what he called the "missing equation" of short-run macroeconomics served the same function as the short-run Phillips curve of the Keynesians. ${ }^{4}$ Monetarism-2, the new classical economics, denies that systematic management of demand can alter the paths of real economic variables.

\section{Real-World Challenges to the Consensus Model in the 1970s}

No one foresaw in 1970 the main economic events of the decade or the formidable challenges those surprises would pose for macroeconomics and stabilization policy. We macroeconomists were caught unawares. It was not simply that our models, theoretical and econometric, now had to be applied to novel situations. Worse than that, the shocks of the 1970s required some fundamental rethinking and rebuilding. From an American perspective, the main events were of three kinds: the increased openness of the U.S. economy and the integration of U.S. financial markets with those overseas, the scrapping of the Bretton Woods system of adjustable exchange parities and its replacement by a regime of marketdetermined exchange rates with largely uncoordinated national interventions, and the predominance of price, supply, and demand shocks from sources other than government policies and the domestic industrial economy. These events all damaged the consensus framework sketched above.

4. Milton Friedman, "A Theoretical Framework for Monetary Analysis," Journal of Political Economy, vol. 78 (March-April 1970), pp. 221-22. 
PRICE AND SUPPLY SHOCKS

The main variable determinants of inflation in the past decade, particularly of the prices that concerned the public and worried their governments, were not those identified in the model. They were not domestic nonagricultural wages and prices. They were not prices in the fixprice sector but in the flexprice sector, food and raw materials. They were not mainly domestic prices, but prices of internationally traded goods. They were strongly influenced by foreign demands and supplies, and by foreign exchange rates. They were, most spectacularly, oil prices set by a cartel of foreign governments and the prices of other energy resources.

The consensus view did not prepare us, or our audiences in the public and in policymaking circles, for these developments. How do they influence the NAIRU or natural rate? How do they alter the short-run trade-off? How long does the bulge in inflation rates following a major one-shot increase in a specific price last? How much and for how long does it raise the basic domestic wage-price inflation rate that was the centerpiece of our analysis? ${ }^{5}$

A central supposition of the "neoclassical synthesis" in macroeconomics was the separation of long-run supply trends from short-run demand fluctuations. Stated without great oversimplification, the view was that the trend of actual output is supply-determined, governed by the steady accretion of labor, capital, and technology. The trend represented equilibrium, analyzable and understandable by neoclassical tools focusing on the intertemporal choices of savers and investors. Short-run fluctuations around the trend were demand-determined disequilibria, analyzable and understandable by Keynesian tools upgraded and modernized. In practice the smooth trend could be fairly well estimated by "potential output," combining labor force and productivity growth; and Okun's Law captured the empirical regularities of employment-output responses to demanddetermined deviations from potential.

In the 1970s it became impossible to rule out short-run variations in capacity supply and to take for granted that fluctuations in production

5. For analysis of "supply shocks" and inflation, see: Robert J. Gordon, "Alternative Responses of Policy to External Supply Shocks," BPEA, 1:1975, pp. 183204; James L. Pierce and Jared J. Enzler, "The Effects of External Inflationary Shocks," BPEA, 1:1974, pp. 13-54; and Edward M. Gramlich, "Macro Policy Responses to Price Shocks," BPEA, 1:1979, pp. 125-66. 
were demand-driven. For example, how much of the decline in output in the 1974-75 recession was compelled by supply factors? How large were GNP "gaps" during the recovery of 1975-79? These were and are matters of doubt and dispute. Supply constraints, in this context, have three distinct meanings.

The first concerns the level and growth rate of the nation's capacity to produce, as measured by constant-price gross value added by U.S. factors of production. This is the concept underlying estimates by the Council of Economic Advisers of the economy's aggregate potential output at a standard rate of employment of the labor force. During the decade it became more difficult to identify potential output and to predict its path. In principle, increased costs of imported materials and final goods do not directly alter potential. But they may have had indirect effects. Toward the end of the decade, average productivity of labor virtually ceased to grow, for reasons not yet well understood. A related puzzle was the apparent decline in the Okun's Law coefficient from 3 percent of GNP per point of unemployment to around 2 percent. ${ }^{6}$ After 1974 employment was surprisingly - disappointingly or pleasantly depending on point of view-high relative to GNP.

A second meaning is the volume of goods and services obtainable for final use by American resource inputs at a given rate of utilization. Potential in this sense was significantly reduced by adverse turns in U.S. terms of trade with the rest of the world. OPEC oil price increases were the most spectacular source, and in addition the dollar depreciated against other currencies by more than their inflation differentials.

A third sense of supply constraint refers to the markets for factors of production, particularly labor. The rise in real oil prices lowered the schedules of marginal productivity of factors complementary to petroleum and other forms of energy. If these factor markets were initially in equilibrium, with supplies positively dependent on real wages or quasi-rents, their employment would have to fall to restore equality of demand price and supply price. This phenomenon would be registered in potential GNP through the decline in labor force participation rather than in productivity. It is this scenario some observers have in mind in attributing postOPEC shortfalls of GNP to supply rather than demand. ${ }^{7}$ Another way to

6. Peter K. Clark, discussion of George L. Perry, "Potential Output and Productivity," $B P E A, 1: 1977$, pp. 55-58.

7. See, for example, Michael Bruno and Jeffrey D. Sachs, "Supply versus Demand Approaches to the Problem of Stagflation," forthcoming in Weltwirtschaft- 
represent this scenario is to recall the old graphical summaries of shortrun macroeconomic systems into aggregate demand and supply curves, each relating the absolute price level to output. An external or sectoral supply shock shifts the supply curve to the left.

Whatever the correct qualitative and quantitative answers to the questions raised, the basic macro models were ill-equipped to provide them. They were too focused on demand, too oriented to a closed economy, and too little disaggregated in both products and factors.

\section{THE NEW INTERNATIONAL MONETARY NONSYSTEM}

Even on its familiar turf, aggregate demand and its management, macroeconomics was not ready for the international developments of the 1970s. Theoretical models inherited from the 1960s were an inadequate guide. The United States is not exactly a small open economy that adapts to interest rates, prices, and demands determined overseas. Its monetary policies play a major role in determining international interest rates, and instruments denominated in different currencies are not such perfect substitutes that policies and events cannot create variable differentials in rates. Asset stocks were unthinkingly ignored in earlier extensions of Keynesian flow models to open economies, but the recent concentration on stock equilibrium, with the slogan that the exchange rate is an asset price, did not do justice to entanglement of capital and current account transactions. ${ }^{8}$

The promise that floating rates would insulate economies from foreign shocks and allow national governments to pursue autonomous monetary policies never had solid theoretical foundation, and it was falsified by events. The faith that exchange speculation would be stabilizing was

liche Archiv; and Jeffrey D. Sachs, "Wages, Profits, and Macroeconomic Adjustment: A Comparative Study," BPEA, 2:1979, pp. 269-319. For a review of the controversy, see Alan S. Blinder, Economic Policy and the Great Stagflation (Academic Press, 1979).

8. On these developments, see Pentti J. K. Kouri and Jorge Braga de Macedo, "Exchange Rates and the International Adjustment Process," BPEA, 1:1978, pp. 111-50; James Tobin and Jorge B. de Macedo, "The Short-Run Macroeconomics of Floating Exchange Rates: An Exposition," in John S. Chipman and Charles P. Kindleberger, eds., Flexible Exchange Rates and the Balance of Payments: Essays in Memory of Egon Sohmen (Amsterdam: North-Holland, forthcoming); and Rudiger Dornbusch and Paul Krugman, "Flexible Exchange Rates in the Short Run," $B P E A, 3: 1976$, pp. 537-75. 
sorely tried by spasms that were independent sources of monetary and economic disturbance. The attacks on the dollar in 1974-75 and 1977-78 are examples. The decline in the dollar exceeded what could be attributed to purchasing power and cost parities or inflation differentials, or any sober assessment of longer run economic prospects. The mood that had seized the market in the fall of 1978 was quickly dissipated by President Carter's speech of November 1, but the speculators had forced the administration to change policy. In the climate of the 1970s there were no firm bases for estimates of future equilibrium exchange rates on which speculators could converge. Instead they often seemed to converge on unanchored opinions about other speculators' opinions. In these circumstances, a large element of macroeconomic policy is the making of announcements and the taking of measures that impress the foreign exchange markets; the intangible assets so purchased can depreciate rapidly.

Self-propelled, and at least temporarily self-justifying, speculation is not the only source of possible instabilities in the macroeconomic mechanisms of national economies with distinct currencies, linked by trade and financial transactions. The wealth effects of exchange rate adjustments are stabilizing when countries have long positions in assets denominated in other currencies, but can be destabilizing when they have foreign currency debts. The trade effects are stabilizing when the well-known elasticities conditions are met, but can be destabilizing when they are not. The so-called $J$ curve is based on the perception that elastic demand and supply responses take time. If they are not foreseen in the exchange markets, "vicious" and "virtuous" cycles can acquire momentum. In a vicious cycle, depreciation raises domestic prices and inflation rates; initially the trade accounts move adversely; these impacts, magnified by currency speculation, bring further depreciation. In a virtuous cycle, everything goes right. These patterns provide one reason that weak currencies stay weak and strong currencies remain strong.

Open-economy models have important implications for demandmanagement policies. With floating rates, these measures manage exchange rates, too, and inevitably acquire a "beggar-my-neighbor" or sauve qui peut flavor. Expansionary monetary policies that gain export demand by exchange depreciation and tight policies that attract foreign funds and mitigate domestic inflation by appreciation are cases in point. One nation's fiscal stimulus, on the other hand, may spill, by higher interest rates and appreciation, into its partners' economies, with positive output and price effects that may or may not be welcome. 
The first-approximation consensus that price-output paths are independent of the fiscal-monetary mix was impaired by the shift to floating exchange rates. Monetary easing offset by fiscal tightening lowers domestic interest rates and depreciates domestic currency. Assuming the depreciation feeds into domestic prices, this mixture raises the price level corresponding to any given aggregate output. This effect is less important for the United States than for more open economies, but here it has become an additional reason against relying on monetary stimulus in cyclical recoveries.

\section{Supply-Side Macroeconomics and Stabilization Policy}

I shall discuss three topics next: the macroeconomic consequences of OPEC and energy constraints, the short-run aggregate supply relationship between price level and output, and possible policies to increase supply in the short and long runs.

\section{OIL AND MACROECONOMIC POLICY}

I referred above to the question of whether the paths of output and unemployment after 1973 were supply-constrained, that is, OPECconstrained, or demand-constrained. The 1974-75 recession and the low recovery path of 1975-78 cannot be attributed to the unavailability of oil. After OPEC-1 oil imports were elastically available to the United States at the higher dollar price. Even if oil consumption per unit of domestic value added was irreducible, the same potential output could be achieved by buying the same quantity of oil. The real loss to the country, in possible consumption, could not in principle exceed the extra cost of the imports, about 1.5 percent of GNP. Substitutions for oil in production and consumption would diminish this loss.

OPEC made energy-guzzling capital goods-of both producers and consumers-obsolete in the sense that they would not be replaced by capital of similar design. But those that had not worn out did not suddenly become uneconomical to use. They would be scrapped in favor of energy-efficient models, Alfred Marshall told us, only if and when the total costs of buying and using the new were less than the variable costs of operating the old. In the interim, their quasi-rents would decline enough to signal that they are not worth replacing-a competitive story 
that has some difficulty coming through in a world of markup pricing in which consumers are asked to provide new capital in the quasi-rents of the old. Confusion on these elementary points seems to have led to some exaggerated estimates of the effects of OPEC on domestic aggregate supply.

There is no evidence of withdrawals of factor supplies because of their inability to earn the same real returns as before OPEC-1. Labor in the United States absorbed a 3.5 percent cut in real (deflated by the consumer price index) hourly wage rates during the year following the OPEC shock. In 1979 OPEC-2 chopped off another 3 percent. Real wage gains in the intervening three years fell far short of pre-1973 experience. Nevertheless, money wages did not accelerate. Labor force growth was so relentless that it was commonly blamed for the persistence of unemployment. By 1979 employment actually had risen 15 percent over 1973. Altogether the real cut in the 1975 wage bill, $\$ 32$ billion (even without any allowance for normal growth of real wages), was more than enough to pay the extra cost of the oil imports. The same was true of the almost $\$ 45$ billion cut in 1979. Moreover, the impact of the OPEC price increase on labor was diluted by internal price controls; domestic oil suppliers, forced to forgo part of the gains from the rise in the world price, in effect absorbed part of the national burden.

Adjustment to the OPEC shock without significant deviation from the tracks of potential output and employment was neither technologically infeasible nor inconsistent with market-clearing real wages. But it did require a big upward jump in paths of money prices. The real wage cuts occurred by price bulge, not by downward departure from the previous money-wage track. This is the scenario Keynes of the General Theory would have predicted. The oil shock shifted up and to the left the aggregate supply schedule, raising the nominal price level needed to induce any given real GNP. But, assuming the schedule was upward-rising in price-output $(p-Y)$ space, an accommodative policy moving the demand schedule up and to the right could hold the previous output path.

The drain of purchasing power to OPEC was, given the low short-run elasticity of U.S. demand for oil and the low propensity of the oil exporters to spend their receipts, a negative demand shock comparable to a domestic excise tax. The quasi-monetary effects depend on the distribution of the exporters' investments between dollar assets and other currencies, and on which dollar assets they choose. Dollar investments may 
account for more or less than the U.S. share of the oil exporters' current account surplus. An even balance, with an amount equivalent to our trade deficit to those countries channeled into U.S. government debt, would make the case the same as a comparable local tax devoted to reducing the supply of government debt. A greater OPEC preference for dollars over the currencies of other importers would appreciate U.S. currency, with possible negative effects on demand but favorable effects on prices. Among dollar assets, greater preference for equities and real assets, relative to money and government debt, would somewhat mitigate the primary contractionary effect of the "tax." The major point is that the price increase restricts aggregate demand in the importing countries as a group. Unchanged monetary and fiscal dial settings, a fortiori more antiinflationary dial settings, are bound to lead to contractions in real economic activity.

The first OPEC shock will probably be unique in several important macroeconomic respects. After the shocking increase of over 400 percent in 1973-74, the dollar price was raised little further until 1979. Inflation and exchange depreciation eroded the real price. For the United States it was 12 percent lower in 1978 than in 1974. Meanwhile, U.S. oil imports increased almost 50 percent from 1975 to their peak in 1977. In these circumstances oil imports were no barrier to recovery and expansion, beyond the tribute exacted by the foreign suppliers.

More serious problems arose when U.S. recovery and growth, and that of other oil importers, raised demand to the limits of the cartel's willing supply, a supply reduced by political events in the Middle East. The upsurge of spot prices triggered the second OPEC shock of 1979. With the price now clearing the market of supplies that evidently accord with the producing countries' intertemporal optimizations, the real price of oil cannot be expected to fall as it did between 1975 and 1979. Indeed, the real price should rise roughly at the real rate of interest that the producers can earn by extracting and selling the oil. Moreover, political mishaps and economic recalculations can change OPEC supply limits at any time.

The year 1979 made clear the macroeconomic consequences of encountering the OPEC supply ceiling, sharp boosts of oil prices and another bout of double-digit inflation. In a sense, contractionary macroeconomic policies, here and in other countries of the Organisation for Economic Co-operation and Development, can be seen as a means of 
containing oil demand through the income effects of slowing real economic activity. And in this indirect sense the current recession was triggered by an encounter with a supply constraint. But the decline of output will undoubtedly exceed what is needed to hold oil demand within current OPEC supply limits.

For the United States the macroeconomic difficulties of OPEC-2 were exacerbated by the vulnerability of the dollar to continued evidence of U.S. dependence on imported oil and of inflation rates that would trigger further escalation of OPEC dollar prices. This raised the specter of a vicious cycle of trade deficits, depreciation, oil price boosts, and inflation -a risk that undoubtedly helped motivate the Federal Reserve's restrictive policies of October 1979 and February 1980.

The clear lesson is that the United States and other oil-importing countries must find more efficient means of reducing oil demand than general recession and stagnation. Otherwise the 1979 crunch will recur whenever their growth at normal levels of economic activity collides with OPEC supply ceilings. And otherwise they will have no bargaining power vis-à-vis the cartel. This is the reason why decontrol of energy prices, and, indeed, even further increases in the relative prices of petroleum products to American consumers, make sense on macroeconomic as well as microeconomic grounds.

\section{THE AGGREGATE SUPPLY SCHEDULE}

Long before the Phillips curve, short-run macroeconomic models included the aggregate supply schedule, relating the price level to real output. The Phillips curve shifted attention one derivative, relating the rate of change of prices to output. The two models are compatible. But it is the old aggregate supply curve that is the more relevant for supply-side macroeconomics.

At the classical pole this supply curve was vertical; at the vulgar textbook Keynesian pole, horizontal. The intermediate version attributed an upward slope to one or more of several short-run phenomena:

Money-wage rates are sticky, while the marginal productivity of labor diminishes with unemployment. As a result of rising marginal costs, markups rise along with capacity utilization. This effect, concealed by increasing utilization of hoarded labor during cyclical upswings, may appear only near the top of booms.

Capacity bottlenecks in particular industries and shortages of specific 
kinds of labor are encountered at all stages of expansions, with increasing frequency as the economy approaches aggregate potential.

Supply is price-inelastic in the short run in agriculture and other flexprice extractive industries. Expansion of aggregate demand, therefore, raises these prices sharply.

With a floating exchange rate, additional output means more imports relative to exports. This may mean exchange depreciation and higher domestic price indexes. However, as already observed, the effect of the expansion on the exchange rate depends on the mix of demand-management policies. Here, as in other respects, the apparatus breaks down in the sense that demand and supply price-output relations are not independent of each other.

Although procyclical movements of interest rates may, through the exchange rate, flatten the supply $p-Y$ curve, their direct effects on domestic prices is opposite. Mortgage interest rates go directly into the consumer price index. More fundamentally, heretics from the populist Texas Congressman, Wright Patman, to John Kenneth Galbraith have disputed the orthodox view that tight money policies are anti-inflationary, claiming that borrowers mark up interest charges like other costs. ${ }^{9}$ An induced increase in velocity may accommodate such bootstrap inflation temporarily, but it cannot continue thereafter unless the Federal Reserve provides the money.

Nevertheless, the "Patman effect," a one-shot price adjustment to recover interest costs, may not be as silly as orthodoxy has said. In longrun equilibrium, firms earn enough to pay current interest rates on borrowed and invested capital. The adjustment mechanism that achieves this result usually runs in terms of investment and disinvestment, entry and exit, inspired by discrepancies between quasi-rents and capital costs. But it is at least possible that in imperfectly competitive industries firms anticipate the equilibrium condition by gearing markups to capital costs more or less continuously.

9. With an "Austrian" lag between inputs and outputs, there is an interest component in variable cost. This point has been emphasized in Lane Taylor, "IS/LM in the Tropics: Diagrammatics of the New Structuralist Macro Critique," in William R. Cline and Sidney Weintraub, eds., Economic Stabilization in Developing Countries (Brookings Institution, forthcoming); and Michael Bruno, "Stabilization and Stagflation in a Semi-Industrialized Economy," in Rudiger Dornbusch and Jacob A. Frenkel, eds., International Economic Policy: Theory and Evidence (Johns Hopkins University Press, 1979), pp. 270-89. 
The $p-Y$ curves were features of macroeconomics before the Phillips curve. The implication of the supply curve was that prices would be higher the closer the economy was to its aggregate potential, but stable at each utilization rate. Movement from a lower output to a higher would bring a one-shot price increase. In an inflation-conscious era these changes look like accelerations. In Phillips curve equations, movements up or down the $p-Y$ supply schedule show up in the coefficient on first differences in unemployment, entangled with "speed limit" effects. These jumps in price level are hard for econometricians, policymakers, and private agents to distinguish from changes in the underlying inflation rate.

The aggregate supply schedule itself can shift, as from OPEC price increases and other supply shocks. Protection, farm price supports, minimum wage boosts, and other "self-inflicted wounds" so common in 1977 can also raise the schedule. Some policies, on the other hand, may shift it down. Arthur Okun and others have advocated reductions of indirect business taxes-sales taxes, excises, and payroll taxes-as a means of lowering the price level. ${ }^{10}$ It is not obvious that a reduction of the tax wedge will lead to a fall in prices rather than a rise in wages or profit margins. The rationale of the recommendation is that money wages are conventionally or contractually sticky in the short run, while prices are determined by stable rule-of-thumb or competitive markups on per unit costs inclusive of indirect taxes. The same assumptions also support the view that factor prices will not move up in the short run even if the indirect taxes are replaced by direct taxes.

If successful, these policies achieve in the first instance a one-shot reduction in price level, which will be recorded as a temporary fall in the inflation rate. Will there be any lasting abatement? There will if money wage trends are formally or informally geared to the cost of living, but not if the dynamics of money wages are self-contained, independent of prices. The facts lie between these extremes, with the weight of U.S. experience on the wage-wage dynamic.

\section{SUPPLY-INCREASING POLICIES}

The currently popular meaning of "supply-side" refers to the productive capacity of the economy and to policies to increase its level and

10. See, for example, Arthur M. Okun, "Efficient Disinflationary Policies," American Economic Review, vol. 68 (May 1978, Papers and Proceedings, 1977), pp. 348-52. 
growth. Journalists love simple dichotomies: the Keynesians ignored supply and even, we are told, thought demand would create its own supply ad infinitum. Egged on by the media, economists and politicians have been flocking onto the bandwagon. Faddısm, amnesia, and sloganeering are the least attractive characteristics of our profession. To borrow an aphorism of Paul Samuelson from another context, the Lord gave us two eyes to watch both demand and supply.

Here I find it necessary to set the record straight. Far from being wholly demand-oriented, the neoclassical synthesis paid a great deal of attention to the factors determining long-run growth and to policies that might raise the level and slope of the economy's full-employment path. ${ }^{11}$ These included choosing a monetary-fiscal mix favoring capital formation relative to consumption, a subject discussed elsewhere in this paper; tax incentives for fixed investment, for example accelerated depreciation and tax credits; encouragement of public and private research and development; and investment in human capital by training and retraining on and off the job, and improvement of labor markets to reduce structural and frictional unemployment-both directed to reducing the natural rate of unemployment.

On all these fronts the federal government followed supply- and growth-oriented policies in the 1950s and 1960s, particularly I think in the early 1960s. If these efforts did not yield spectacular results, the main reason is that they are very hard to obtain. It is not that Keynesian economists and policymakers were blind to their importance.

Although we may be confident that increasing the ratio of investment to potential output will raise the capital-labor ratio and raise productivity, we know that the payoff is slow to come. Suppose, to take a not unrealistic numerical example, that business fixed investment is 12 percent of business gross product, that the stock of business capital is 1.5 times business gross product, and that capital consumption is 6 percent of the stock, 9 percent of gross product. The 3 percent of product devoted to net investment increases the stock at 2 percent a year. A sustained rise of 2 percentage points in gross investment would be a spectacular response to any imaginable combination of investment and saving incentives. Eventually, asymptotically, this would raise the capital-output ratio from 1.50 to 1.75 . If the output-on-capital elasticity is one-third, this will raise gross output per effective worker by 8.33 percent, and net consumable income by 5.80 
percent. But at the beginning, capital intensity is increasing at 1.33 percent a year, raising gross output by only 0.67 percent a year, and consumable income initially falls by 1.60 percent.

Welcome as these gains in productivity would be, they clearly do not produce a short-run solution for inflation. They do not lead to a long-run solution either. The growth in productivity bulges during the transition to greater capital intensity but gradually returns to the rate determined by technological progress, unless the investment-output ratio is repeatedly raised. To get a permanent increase in productivity growth, it is necessary to speed up technological progress, and nobody knows how to do that. If it happened, it would be its own reward, but there would not necessarily be a reduction of inflation. Productivity gains will raise real wages, but whether from higher money wages or lower prices our models say not. Countries with dramatically higher productivity growth than ours have sometimes had higher inflation rates, sometimes lower. ${ }^{12}$

An insistent supply-side chorus seeks remedy for the slowdown in business fixed investment in the 1970s in lower taxation of returns to capital. One theme of the diagnosis is that the nation's propensity to save is too low because the rewards for saving have been impaired by the combined impacts of taxation and inflation. I cannot undertake an evaluation here of these alleged effects or of the pro-saving consequences of income tax rate cuts and of liberalized tax treatment of capital gains and of retirement contributions. On the macro plane, the question is whether saving was the binding constraint on investment during the years of weak capital formation, notably 1975-78. The diagnosis assumes that a higher saving propensity would have been absorbed in extra investment rather than in a lower output path, and that increased thrift rather than higher real incomes than those actually experienced was the only source of extra saving. But if real incomes had been higher during the period, saving would surely have been higher, too. In the prosperous years of 1974 and 1979, business fixed investment was 11 percent of GNP, close to its postwar peak.

12. Consumer price inflation in Japan exceeded that in the United States in 1951-54, when the Japanese rate was never below 5 percent. It also exceeded the U.S. rate every year but one from 1960 to 1977 . In a similar comparison between France and the United States, France had the higher inflation rate in all but four years from 1950 to 1978 . Compared with Germany over the same period, the United States had less inflation in 1955-56, 1960-66, and 1971-73. See International Monetary Fund, International Financial Statistics Yearbook, vol. 32 (IMF, 1979), pp. 58-59. 
Alternatively, explanation for the slowdown of business capital formation in the 1970s may be sought in investment demand rather than in saving supply. In these terms the weakness of investment is quite understandable given the excess capacity and high cost of equity capital that characterized most of the period. ${ }^{13}$ These in turn were in large measure the consequences of anti-inflationary policies, actual and anticipated. In this sense the failure of the country to solve its stagflation problem is damaging its long-run potential as well as its current performance. In this sense, too, short-run demand management affects long-run supply.

As supply-side economists have stressed, the taxation of nominal income leads to distortions during periods of inflation. The fact that some of these distortions are deterrents to investment is a rationale for compensatory tax concessions and incentives. Firms that use FIFO (first infirst out) accounting pay taxes on fictitious inventory profits. But the law already invites them to shift to accounting practice that would virtually eliminate this burden. On plant and equipment, the problem is the overstatement of taxable earnings due to depreciation based on historical cost. On the other hand, the tax deductibility of full nominal interest payments is an investment stimulus, which is larger the higher the expected inflation rate. The balance of these two effects varies among firms and types of investment, depending on depreciation rates, debt-equity ratios, and the rate of inflation..$^{14}$ As nominal interest rates have risen along with inflation, corporations have shifted to debt financing. Moreover, some investment-oriented tax concessions were made in the 1970s; the highbracket corporate income tax rate was reduced by 3.2 points and the investment tax credit was liberalized and made permanent. On efficiency grounds, a strong case can be stated for making the taxation of capital earnings more nearly neutral with respect to inflation, whether or not the

13. George M. von Furstenberg, "Corporate Investment: Does Market Valuation Matter in the Aggregate?" BPEA, 2:1977, pp. 347-97; and Peter K. Clark, "Investment in the 1970s: Theory, Performance, and Prediction," BPEA, 1:1979, pp. 73-113.

14. John B. Shoven and Jeremy I. Bulow, "Inflation Accounting and Nonfinancial Corporate Profits: Financial Assets and Liabilities," BPEA, 1:1976, pp. 15-57, and "Inflation Accounting and Nonfinancial Corporate Profits: Physical Assets," $B P E A, 3: 1975$, pp. 557-98.

Incidentally, the loss due to historical cost depreciation accounting cannot exceed the full tax benefit of depreciation no matter how high the inflation rate; hence the marginal loss from an extra point of inflation declines and approaches zero. On the other hand, the gain from deductibility of nominal interest is, given the debt-equity ratio, proportional to the inflation rate. 
balance of the distortions has been unfavorable to business fixed investment.

Likewise, considerations of efficiency-and equity, too-support reforms of individual income taxation that would spare savers taxation of the purely inflationary components of capital gains and interest income. But tax reductions of this kind would presumably be made up by increases elsewhere. The supply-side notion that uncompensated tax concessions to saving will increase the national supply of saving for private capital formation, as a fraction of GNP, is dubious. The fatal flaw is that such concessions are likely to lose more public saving than the private saving they promote unless the rate-of-return elasticity of saving (saving as a whole, not particularly favored assets) is much greater than any credible

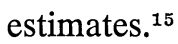

Another plank in the supply-side platform is the proposition that income tax cuts will bring forth vast increases in labor supply and productive effort. The supply elasticity would have to be incredibly large if the increased supply of goods were to exceed the increased consumption demand induced by the tax reductions. What is less relevant is that the elasticity would have to be even larger if tax revenues were not to diminish. ${ }^{16}$

15. Suppose income consumed, $c$, is taxed at rate $t$ and income saved, $s$, at rate $t-u$, and that consumption is a function of both disposable income $y_{d}$, equal to $[y(1-t)+u c] /(1-u)$, and of the after-tax rate of return on saving, $r_{d}$, equal to $[r(1-t)] /(1-u)$. Then, with pretax income, $y$, and return, $r$, given

$$
\frac{\partial c}{\partial u}=\left(\frac{\partial c}{\partial y_{d}}\right) \frac{s}{c(1-u)}+\left(\frac{\partial c}{\partial r_{d}}\right) \frac{r_{d}}{c}=\frac{s}{(1-u) c}\left(\frac{\partial c}{\partial y_{d}}-\frac{\partial s}{\partial r_{d}} \frac{r_{d}}{s}\right) .
$$

The second term in the last parentheses is the elasticity of saving with respect to its return. The first is the marginal propensity to consume, $m p c$, from disposable income. Unless the interest-elasticity of saving exceeds the $m p c$, of which 0.6 is a conservative estimate, the tax concession actually increases consumption. If $r_{d}$ is 0.04 a year, an increase of 100 basis points would raise it by 25 percent. Does anyone think that would increase saving by 15 percent?

16. Let $1 / \beta$ be the elasticity of labor supply with respect to the after-tax wage. Let $\alpha$ be the output-on-capital elasticity in a two-factor Cobb-Douglas production function with constant returns to scale; $\alpha$ is also the elasticity of the schedule of marginal product of labor. Let $\gamma$ be the percentage of after-tax income spent, for simplicity assumed to be identical for capital and labor income. Then a reduction in the tax rate $t$ will reduce the supply of goods net of induced spending-and in this sense will be inflationary-unless $t$ exceeds $(\alpha+\beta) /(1+\beta)-[(1 / \gamma)-1] /(1+\beta)$. It will reduce government revenue unless $t$ exceeds $(\alpha+\beta) /(1+\beta)$. For $\alpha=0.3$, $\gamma=0.8$, and $\beta=3.0$, an improbably low value, the first limit is 0.760 and the second is 0.825 . 
Tax distortions of work-leisure choices and of choices among jobs have been around a long time. The relevant marginal tax rates are not significantly higher now than they were in the 1960s. They remain lower than in European countries whose superior productivity growth excites our envy and admiration. ${ }^{17}$ Despite taxation, the absolute after-tax rewards to additional work are greater than in earlier periods, and greater in the United States than in almost all other countries. If the substitution effects are so important relative to income effects, why has a long-term trend toward leisure been associated with productivity growth? Why has work not increased as its marginal after-tax reward in consumption has progressively risen? An answer consistent with the alleged paramount importance of substitution effects requires a model in which the opportunity cost of work-in leisure off or on the job-rises commensurately with the productivity of work; an example is a model in which technological progress increases the utility of an hour of leisure as rapidly as the productivity of an hour of work.

Whether or not income taxation is in fact seriously depriving the nation

17. The first three columns below give the percentage of an employee's gross earnings taken by national and local income taxes and social security contributions in selected countries in 1976 for three levels of earnings $(100,200$, and 400 percent of the earnings of an average production worker in each country). The figures are for a two-adult, two-child family. In the first two columns all the earnings are due to the husband. In the third column, they are evenly divided between the two spouses. The figures are from Organisation for Economic Co-operation and Development, The Tax/Benefit Position of Selected Income Groups in OECD Member Countries, 1972-1976, a report by the Committee on Fiscal Affairs (Paris: OECD, 1978), table 16(c). The fourth column gives the corresponding marginal rate for an average production worker. The fifth column shows the maximum marginal personal income tax rates in 1976 (1974 for Japan). See ibid., table 6, and pp. 40-86. The U.S. rate on earned income is 50 percent. These figures refer only to central government taxation.

\begin{tabular}{lcccccc} 
& \multicolumn{3}{c}{$\begin{array}{c}\text { Taxes and social security contributions, } \\
\text { by income group }\end{array}$} & & $\begin{array}{c}\text { Maximum } \\
\text { marginal } \\
\text { income }\end{array}$ \\
\cline { 2 - 4 } & 100 percent & 200 percent & 400 percent & & Marginal \\
tax rate & tax rate \\
Austria & 13.3 & 20.8 & 23.4 & 28 & 62 \\
Belgium & 21.9 & 32.4 & 39.1 & 37 & 60 \\
France & 10.0 & 12.5 & 19.0 & 16 & 60 \\
Germany & 27.0 & 28.7 & 38.5 & 34 & 56 \\
Japan & 8.0 & 14.8 & 17.6 & 21 & 75 \\
Netherlands & 31.8 & 35.2 & 37.2 & 42 & 72 \\
Sweden & 35.0 & 53.0 & 54.0 & 63 & 57 \\
United Kingdom & 25.4 & 31.6 & 34.1 & 41 & 83 \\
United States & 17.0 & 22.0 & 29.0 & 32 & 70
\end{tabular}


of work and productivity, it is desirable to mitigate the distortions. Reduction of marginal income tax rates is not the only possibility. If people are working too little, what about taxing commodities complementary to leisure-hammocks, coffee, boats, skis?

At a time when labor force participation rates are setting records, it seems strange that anyone takes seriously the diagnosis behind the legislative proposals of Congressman Kemp and Senator Roth. Some rhetoric hints at an even more miraculous scenario, by which higher takehome wages induce the productivity that justifies them. The first Henry Ford profited from paying well above the market. Presumably he attracted the best and lifted their morale, a trick that cannot be generalized when everybody does it.

As economists have recognized for more than a decade, disincentive problems are acute at the bottom of the income distribution. The multiplication of income-conditioned assistance programs can imply confiscatory marginal taxation of earnings. The congeries of diverse national and state programs, some in kind and some in cash, also distort other choices -including location, family composition, and saving. Rational reform and integration of assistance with personal income taxation and social security could help to reduce both the NAIRU and the depreciation of human capital.

With respect to human capital, as well as to physical capital, demand management has important long-run supply-side effects. A decade of slack labor markets, depriving generations of young workers of job experience, will damage the human capital stock far beyond the remedial capacity of supply-oriented measures.

\section{Monetarism and Stabilization Policies Today}

The crucial issues of the day, as I already observed, are what happens when policies alter nominal GNP, the product of money stock and its velocity, $M V$, not how to change $M V$. In this light, the old monetarist debates about the monetary theory of nominal income are distinctly secondary. But as a veteran of those battles, I will offer some comments and try to clear away some residual debris. 


\section{INFLATION AND ACCOMMODATIVE MONETARY POLICY}

Yes, of course, inflation is a monetary phenomenon, a pervasive reduction in the value of the monetary unit of account in terms of goods and services. Yes, of course, inflation means that the rate of growth of $M V$ exceeds the rate of growth of real output. Yes, of course, the long-run sustainable growth of real output cannot exceed the trend of potential supply, limited by resources and technology. Yes, of course, a necessary condition of a stable price level is that the trend rate of growth of $M V$ equal that of the economy's capacity to produce. But none of these tautological propositions reveal what will be the effects of changes of monetary policy, temporary or permanent.

Clearly the rate of inflation today would be much lower if the path of $M V$ ever since 1960 or even 1970 had been fairly steadily held to, say, 4 percent a year. Clearly there are some paths of the monetary base or of the various monetary aggregates, $\mathbf{M}_{\mathrm{i}}$, that could have achieved that result. What is far from clear is that the paths of real variables-output, employment, investment-would have approached the paths actually realized, or even that current levels of those variables would be the same as their actual values. The Federal Reserve would not have accommodated the fiscal stimuli of the early 1960s, the fiscal excesses of the Vietnam War, the wage explosion of the early 1970s, the later shocks from increases in commodity prices and OPEC prices, and the inflationary pressures these events generated. Economists today differ, and historians doubtless will also, about the shape of such a counterfactual rerun of these two decades. I certainly cannot prove my suspicion that the path of real variables would have been disastrously worse. ${ }^{18} \mathbf{I}$ do think that it is

18. I asked my colleague Ray Fair to check his macroeconometric model of the United States to see what would have happened if the Federal Reserve had rigorously followed a policy of 4 percent growth in $M_{1}$ beginning in 1961. The model balked after a few years at 4 percent but agreed to make a longer run with 5.4 percent. Even then it refused to go beyond 1973:1, by which quarter the downward deviations from the historical path of real GNP, beginning in 1967 and turning into depression in 1970, had brought simulated output to two-thirds of its actual value. Disinflationary gains were minimal, partly because the model contains a strong "Patman effect," which translated astronomical interest rates into high prices. The offset in wage disinflation was surprisingly small, because the "discouraged worker" effect kept unemployment rates below 10 percent despite sharp declines in employment. Fair recognizes that this experiment strained his structural specifications, 
disingenuous to give the impression, so prevalent today, that the whole inflationary experience could have been costlessly avoided by conservative demand management.

Throughout the 1970s accommodation has been the agonizing issue repeatedly facing the monetary authorities. The practice of describing monetary policy in terms of observed growth rates of $\mathrm{M}_{\mathrm{i}}$ is misleading. It does not make sense to say that the policy was or is $x$ percent money stock growth as if that number were something the central bank chooses arbitrarily and gratuitously. For one thing, the marksmanship of the Federal Reserve with respect to endogenous target variables, whether any $\mathrm{M}_{\mathrm{i}}$ or a fortiori $M V$ itself, is bound to be imperfect. More important, when the authorities have chosen policies supportive of continued inflationary growth of $M V$, they have not done so from ignorance of arithmetic, indifference to inflation, or, in my opinion, political pressure. They have done so, rightly or wrongly, mainly because of the perceived consequences of nonaccommodation on the real performance of the economy. The inertia of inflation in the face of nonaccommodative policies is the big issue. To discuss the roots of that inertia and the sources of nonmonetary pressures for accommodation-administered prices, contracts, collective bargaining, distributive conflict, supply shocks, OPEC—is not to commit any vulgar errors or to violate any of the identities stipulated above.

\section{REAL MONEY AND REAL INTEREST}

A related diversion is the repeated charge that nonmonetarists erroneously assume that the government can alter the real quantity of money. Monetarists, in contrast, know that the authorities fix the nominal supply while the real quantity is independently determined by the public's demand. In long-run full-employment equilibrium, price flexibility makes this proposition true (though not quite, because the proportions in which various "outside" monetary assets are supplied to the public will determine their relative real quantities). But in the short-run context of stabilization policy, prices are not flexible enough to make the real quantity of any monetary aggregate independent of its nominal supply. Prices are one

which were designed for more modest deviations from observed history. Moreover, both he and I are aware that so radical a difference of policy would have changed the whole structure and the whole history. $\mathrm{He}$ is not necessarily implicated in my conclusion that no one has the right to assume that a monetarist policy would have entailed no serious real cost. 
way, but not the only way, in which money demand adjusts to changes in money supply. Nominal interest rates are another. Figures 2 and 3 show the short-run congruence of changes in nominal and real monetary stocks, the monetary base, $\mathrm{M}_{1 \mathrm{~B}}$, and $\mathrm{M}_{2}$. As in the case of $M V$ (figure 1), variations in nominal and real stocks are strongly positively correlated, except during the periods dominated by external price shocks. Real quantities show the larger amplitude, contrary to the monetarist notion that endogenous price movements convert unstable nominal monetary supplies into stable real monetary demands.

Another extreme monetarist proposition is that the monetary authorities cannot alter the real rate of interest. Trying to do so by fixing a nominal interest rate will only lead to such monetary growth, actual and expected, as creates the inflation rate that converts the nominal interest rate into the economy's natural real rate. This is another proposition with a considerable quantum of truth for the long run. It falls short by failing to allow for what is sometimes called the Mundell effect, by which inflation lowers real rates by inducing substitution away from monetary assets with zero nominal interest. ${ }^{19}$ It also makes no allowance for the nonneutrality of real-world taxes with respect to inflation rates, a point discussed above in connection with "supply-side" advocacy of fiscal reforms. In the 1970s after-tax nominal interest rates rose far less than the inflation rate. For example, the tax-exempt rate rose only 120 basis points from 1972 to 1979. Rates on Aaa corporate bonds rose about the same if the marginal tax rate effective in that market is assumed to be 50 percent. For short-run stabilization policy, the important point is that, given the persistence and inertia of inflationary trends and expectations, the central bank can and does alter real rates of interest by measures that change the nominal rate. The notion that intertemporal substitutions in production and consumption are so perfect as to maintain constant real interest rates is one of the more bizarre propositions of this wild decade. ${ }^{20}$ Figure 4 shows nominal commercial paper rates and "real" rates calculated in two ways, from the GNP deflator's inflation during the previous year and from the actual inflation during the coming half-year.

19. Robert Mundell, "Inflation and Real Interest," Journal of Political Economy, vol. 71 (June 1963), pp. 280-83; and James Tobin, "Money and Economic Growth," Econometrica, vol. 33 (October 1965), pp. 671-84.

20. Eugene F. Fama, "Short-Term Interest Rates as Predictors of Inflation," American Economic Review, vol. 65 (June 1975), pp. 269-82. 
Figure 2. Rates of Growth of the Monetary Base and $M_{1 B}$, Nominal and Real, 1970:1-1979:4a

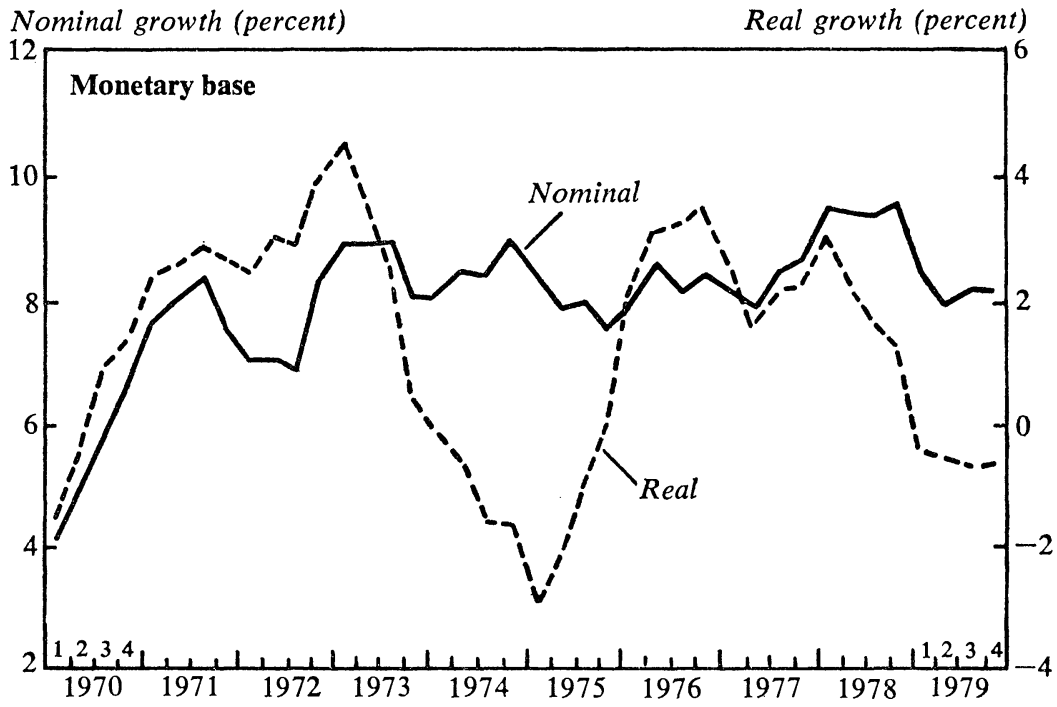

Nominal growth (percent) Real growth (percent)

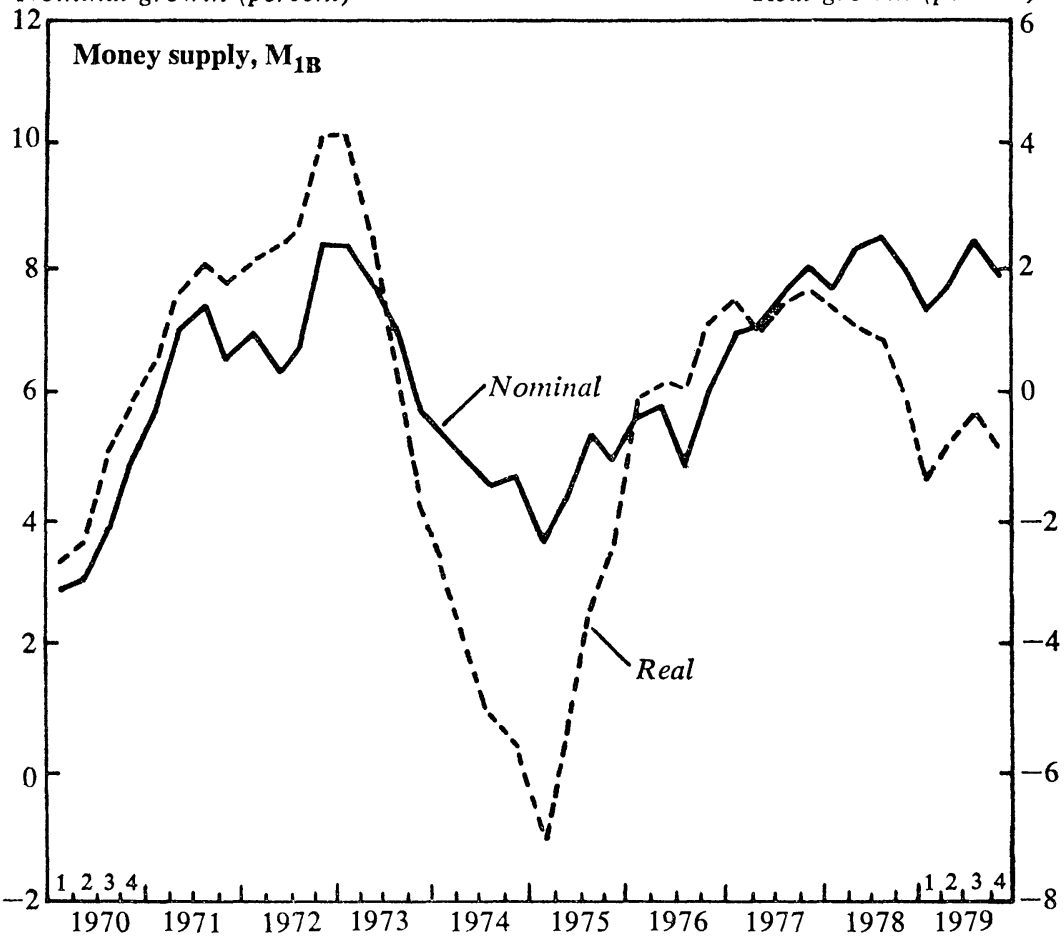

Source: Board of Governors of the Federal Reserve System.

a. Data are percent changes from a year earlier. The nominal series were defiated by the GNP deflator to obtain real series. 
Figure 3. Rates of Growth of $M_{2}$, Nominal and Real, 1970:1-1979:4^

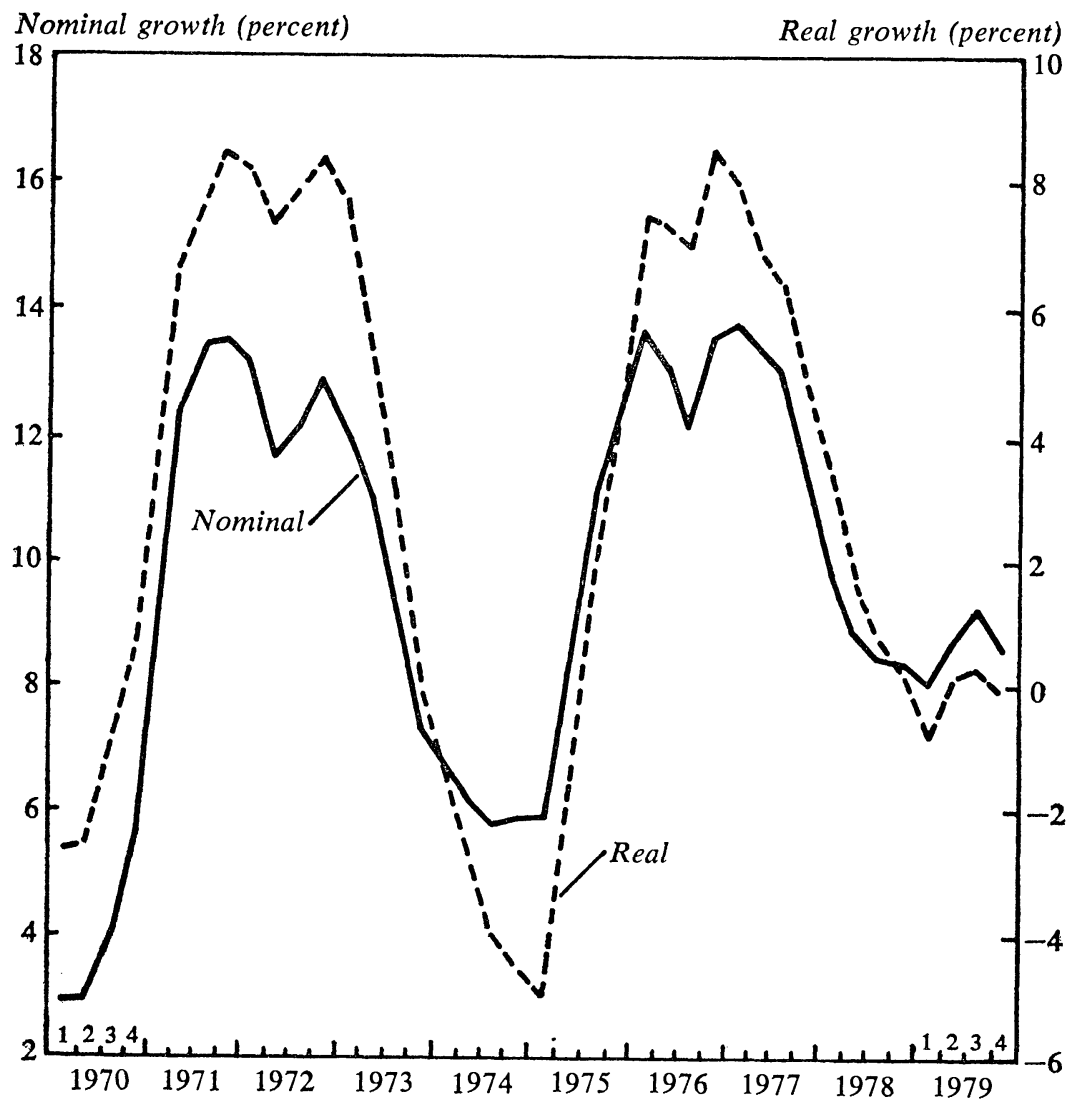

Source: Board of Governors of the Federal Reserve System.

a. Data are percent changes from a year earlier. The nominal series was deflated by the GNP deflator to obtain the real series.

WHICH MONEY STOCK? FUNDAMENTAL AND

\section{TRANSACTIONS MONETARISM}

A continuing theoretical and practical problem of monetarism has been the identification of the aggregate that is the monetary fulcrum of the economy, the exogenously supplied stock to which all endogenous variables of monetary dimension adjust. I discern two disparate approaches, which can be termed fundamental monetarism and transactions monetarism, respectively. The fundamental approach, motivated by the desire to find real-world counterparts for the variables of simple theo- 


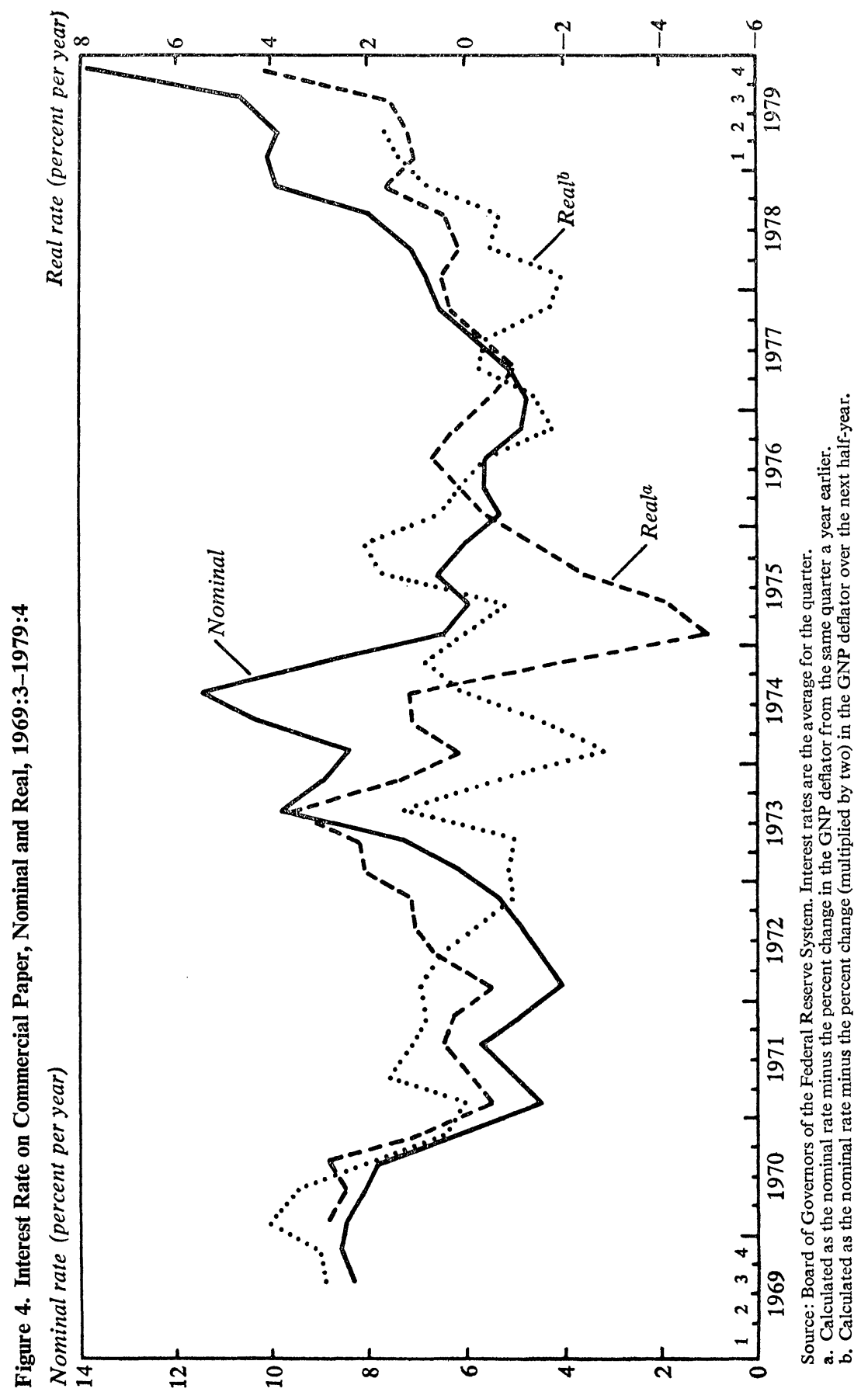


retical models, focuses on the monetary base, whose quantity is clearly under government control and is dollar for dollar net private wealth, unmodified by offsetting private debts.

The difficulties are manifold. What about other government obligations to the public, promises to pay the same base money in a few days or years or decades? The conditions on which they can be totally disregarded, as offset by taxpayers' estimates of future tax liabilities, are quite special and improbable. Indeed, some recent monetarists go to the other extreme, encompassing the entire interest-bearing debt in their concept of the monetary base. What about the fact that the government has lent, so to speak, its fiat to banks and guaranteed their demand liabilities, while keeping their total loosely connected to the monetary base? These and other complexities make the velocity of the monetary base quite variable. The fairly steady growth of the base in recent years has not prevented considerable variation in rates of increase of $M V$, prices, and real output.

Fundamental monetarism relies on the "classical dichotomy" and the neutrality of money. Transactions monetarism, a more pragmatic and empirical version, relies on the technology of transactions. It therefore emphasizes the key role of those dollar assets that are used in making payments and seeks to control the economy by controlling the supply of such media.

The endemic difficulties have been well known for a long time. The recent events that pushed the Federal Reserve to redefine the monetary aggregates were particularly striking examples. These included the spread of new transactions media, many bearing market-determined interest rates and many issued by nonbanks; the increased substitutability of interest-bearing assets for checking accounts; the availability of overdraft lines through credit cards, and so on. The recent definitional changes and extensions of reserve requirements are attempts by the Federal Reserve to cope with these explosions of financial innovation.

But the truth is that expenditures on goods and services are not limited by the stock of transactions media. Nor does expansionary monetary policy work by providing citizens, without their volition, more transactions money than they want, which they then spend because it is burning holes in their pockets.

The empirical upward trends in velocity of $\mathrm{M}_{1}, \mathrm{M}_{1 \mathrm{~A}}$, and $\mathrm{M}_{1 \mathrm{~B}}$ cannot be a law of nature. They reflect in imperfectly known and variable pro- 
portions the upward trend in nominal interest rates, presumably not a law of nature, plus innovative economies in cash management, some induced and some exogenous, some reversible and some not, plus liberalization of government regulations of banks and other financial institutions. When liabilities bearing market interest rates are included in the aggregates, the demand for the aggregates is surely not the same, or sensitive to market interest rates in the same degree, as when they were not.

\section{TARGETS AND INDICATORS}

The use of targets for monetary aggregates to signal the intentions of the central bank has the advantage that changes in the targets tell in which direction the Federal Reserve will be trying to move the economy. The longer the horizon of the targets the more indicative the signals are, especially for economic agents outside the financial sector. Targets for a year ahead or longer may, for example, indicate a resolutely unaccommodating, but not wholly credible, stance toward shocks in prices and foreign exchange rates.

As Poole showed, ${ }^{21}$ quantitative targets do not protect the Federal Reserve and the economy against " $L M$ " surprises-which do occur, for example, "the case of the missing money." 22 They do defend moderately well against " $I S$ " surprises, but not as well as a policy that would counteract the velocity changes induced by such surprises. It makes no sense to define as a "neutral" policy one that allows $M V$ to respond endogenously precisely only to the extent that the public is induced by interest rate increases and other incentives to make economies of cash management. The institutions, habits, and technologies that determine those elasticities have little to do with the desirable degree of output and income response to fiscal measures or to exogenous changes in consumer, business, or foreign spending.

The money and financial markets have become obsessed with translating current information on deviations of actual aggregates from targets into information on future interest rates. Given the noise in weekly money stock reports and given that at times the Federal Reserve may have good

21. William Poole, "Optimal Choice of Monetary Policy Instruments in a Simple Stochastic Macro Model," Quarterly Journal of Economics, vol. 84 (May 1970), pp. 197-216.

22. Stephen M. Goldfeld, "The Case of the Missing Money," BPEA, 3:1976, pp. 683-730. 
reasons for moving the targets toward the actuals rather than vice versafor example, in response to events in foreign exchange markets-this obsession probably puts more noise than rationality into interest rates and asset prices.

I think it would be preferable for the Federal Reserve to announce target ranges for $M V$ growth a year ahead, indeed several years ahead. Alternatively, these could be expressed as two-dimensional brackets for GNP inflation and real GNP growth. This would leave the Federal Reserve free to follow policies consistent with these substantive targets without staking its credibility on hitting targets of only instrumental or indicative significance. The proposed targets would make clear the message the Federal Reserve has been trying to convey: that the economy's output path will be better when its wage and price performance improves. Disguised and confused in numbers for various esoteric $\mathrm{M}_{\mathrm{i}}$, this message does not now reach the audience that matters, especially when the accompanying rhetoric suggests that variations in these aggregates affect price inflation rates directly and costlessly regardless of the behavior of business and labor. The two-dimensional brackets are desirable because the Federal Reserve does not necessarily wish to hold the economy to a point-forpoint trade-off between inflation and real growth. Ranges would allow not only for inevitable errors of forecast and control but also for flexibility in responding to shocks from international commodity and currency markets.

Coherent stabilization strategy requires that the Federal Reserve's targets be consistent with the economic assumptions and objectives of the federal budget. The present compartmentalized procedures, both in the executive branch and in the Congress, do not guarantee consistency or provide for conscious and deliberate decision about the fiscal-monetary mix. The Federal Reserve's objectives are expressed in the $M_{i}$, whose implications for economic outcomes are left vague and fuzzy. If they were expressed in prices and output, then the congressional oversight of monetary policy would blend into the congressional budget procedures, and the makers of monetary and fiscal policy would be forced to talk to each other seriously about their joint endeavor. The Federal Reserve Board probably finds the present dualism protective of its independence and of its advantage in having twelve or more moves a year to the budget-makers' one. However, its chairmen regularly complain that Congress and the president saddle it with too much of the joint work of stabilization, and 
the unpleasant part at that. More Federal Reserve input in the budget process could produce a more balanced fiscal-monetary mix.

\section{THE MONETARY-FISCAL MIX}

In the 1950s and 1960s the neoclassical synthesis generated the doctrine that monetary and fiscal measures should be regarded as substitutes in supporting a given path of real GNP. Substitution of fiscal for monetary restraint would be a pro-growth or future-oriented policy, nudging the composition of national expenditure in favor of private capital formation and away from private or public consumption. This proposition depended on some empirical assumptions: that interest rate reductions and easing of credit stimulate investment more than they deter saving, while generalized tax increases or public expenditure reductions hit consumption more than investment. These are essentially the same grounds on which many people argue that expansionary fiscal measures crowd out capital investment. (A monetarist believer in 100 percent crowding out would not see any opportunity for offsetting the aggregate-demand consequences of monetary expansion or contraction by fiscal measures. And a believer in the Ricardo-Barro equivalence of postponed and current taxation would deny that any manipulations of public debt and taxes will affect national saving and investment.) ${ }^{23}$

The monetary-fiscal mix also affects the balance of payments or the exchange rate. Substitution of fiscal for monetary restraint is "bad" for a country trying to defend its currency, a chronic plight of the United States since 1960. In the 1960s defense of the overvalued dollar took precedence over the dedication of the demand-management mix to domestic growth; this was one reason for reliance on tax stimulus during the 196165 recovery. With the gold window closed and the dollar floating in the 1970s, this priority became less compelling. In principle a low interest rate and low exchange rate, offset by taxes bearing mainly on consumption, would be favorable to both foreign and domestic investment. But for many reasons, including the price effects mentioned above, such a policy was not feasible.

Even without foreign exchange considerations, the politics and administration of fiscal and monetary policy work against a growth-oriented

23. Robert J. Barro, “Are Government Bonds Net Wealth?” Journal of Political Economy, vol. 82 (November-December 1974), pp. 1095-1117. 
mix. Fiscal expansion is the natural governmental response to recession and unemployment, and monetary restriction is the most available and acceptable weapon against inflationary booms. There is even some economic logic to this division of labor-the suspicion that while monetary restriction is very effective in cooling a hot economy, monetary ease is "pushing on a string" at the trough of a business cycle. In any case, a sequence of cycles with these asymmetries in policy creates a trend toward consumption at the expense of investment.

At least one more instrument is needed, and an obvious place to find it is in the structure of taxation. This indeed was the sophisticated rationale for the introduction of the investment tax credit in 1962, a specific stimulus for investment and only for domestic investment.

Addressing the same issues today and sharing widespread concerns about lagging capital formation, Martin Feldstein argues for a tighter monetary policy, along with new corporate tax reductions or tax incentives for investment. ${ }^{24}$ His measure of monetary tightness is the after-tax long-term interest rate adjusted for inflation. He says this rate has been too low. The Federal Reserve, in keeping real interest rates before tax at levels comparable to those of previous prosperities, has, perhaps inadvertently, lowered the after-tax real interest rates that matter for investment and saving. Inflation, given that full nominal interest is taxable to creditors and tax deductible to debtors, is responsible for this outcome. Evidently he believes that this monetary policy, together with recent federal budgets, add up to an excessively expansionary and inflationary package of demand management. This judgment, whatever its merit, is separable from the proposition that the composition of the package errs in the direction of monetary ease.

On this point, the policy mix, Feldstein calls attention to the stimulus that the low after-tax real rates give to investment in owner-occupied homes, whose yields in service and capital appreciation are untaxed. Presumably the same low interest rates should be a stimulus to corporate investment in plant and equipment. But the argument is that such rates magnify the relative bias of the tax system in favor of residential investment. It may also be contended that housing is a particularly inflationary allocation of demand.

24. Martin Feldstein, "Tax Rules and the Mismanagement of Monetary Policy," American Economic Review, vol. 70 (May 1980, Papers and Proceedings, 1979), pp. 182-86. 
Given the aggregate real GNP available for private domestic disposition, there are three final uses among which it can be divided: consumption, residential investment, and nonresidential investment. The division can be affected by the mix of policies as among taxes bearing on the three uses and monetary measures. Feldstein wants to raise the share of nonresidential investment by specific tax concessions, obtaining the resources principally from residential construction. This is to be done by monetary tightening, which he argues will affect home building more adversely than fixed investment. But it will affect fixed investment too, working against the tax incentives. The two opposing levers will have to be worked very hard to obtain the desired allocational effect.

A better and surer way to shift resources out of residential construction would be to eliminate or diminish the tax favoritism for home ownership. Should not an economist recommend this route even if it is not politically feasible? Furthermore, it is not clear why more of the resources for business investment should not be obtained by taxes bearing principally on consumption. Is the mix of consumption and total investment, residential plus nonresidential, just right?

\section{FISCAL POLICY}

Fiscal policy was in general a stabilizing influence during the 1970s. Certainly the "built-in stabilizers" damped the two recessions, in particular the severe downturn of 1974-75. The whopping deficits of the mid1970s were mainly symptoms of their performance. Active countercyclical policies promoted recoveries from the two recessions. They also applied restraint in later stages of the recoveries, although critics would say too little and too late.

In figure 5, I show three measures of fiscal policy. One is simply the ratio of government purchases of goods and services to potential output. State and local purchases are included, on the grounds that their finance is so entangled with the federal budget that the total for all governments is more indicative than federal purchases alone. As figure 5 shows, this ratio has steadily declined over the decade and has not been a source of cyclical disturbance. The second measure is the high-employment federal deficit as a percent of potential output. This has generally moved countercyclically, except for the 1974 shift to surplus.

The third series is a rough measure of changes in the real market value of outstanding federal nonmonetary debt. It measures net real interest 
Figure 5. Measures of Fiscal Policy, 1969-80

Percent of potential GNP

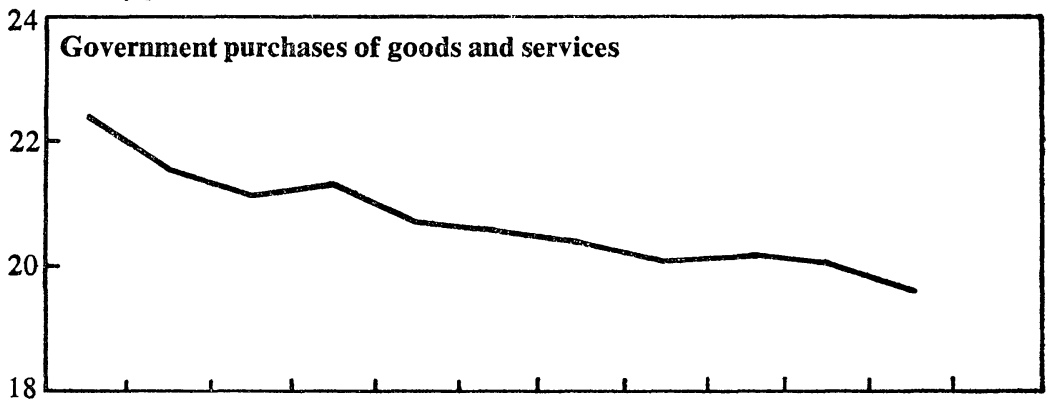

Percent of potential GNP

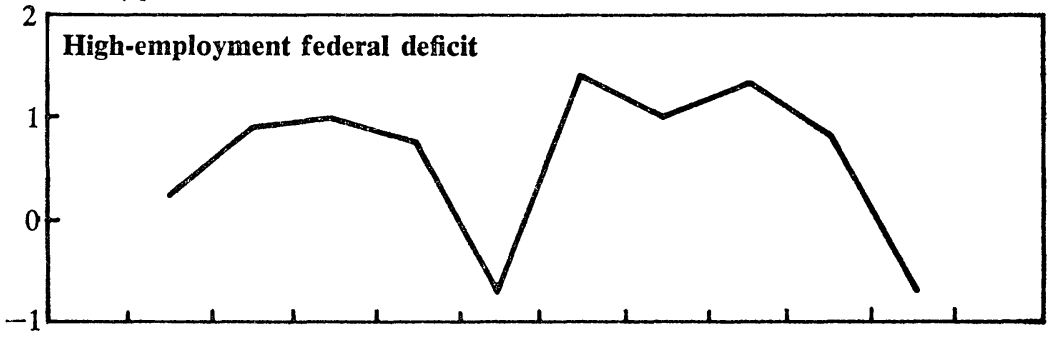

\section{Percent change}

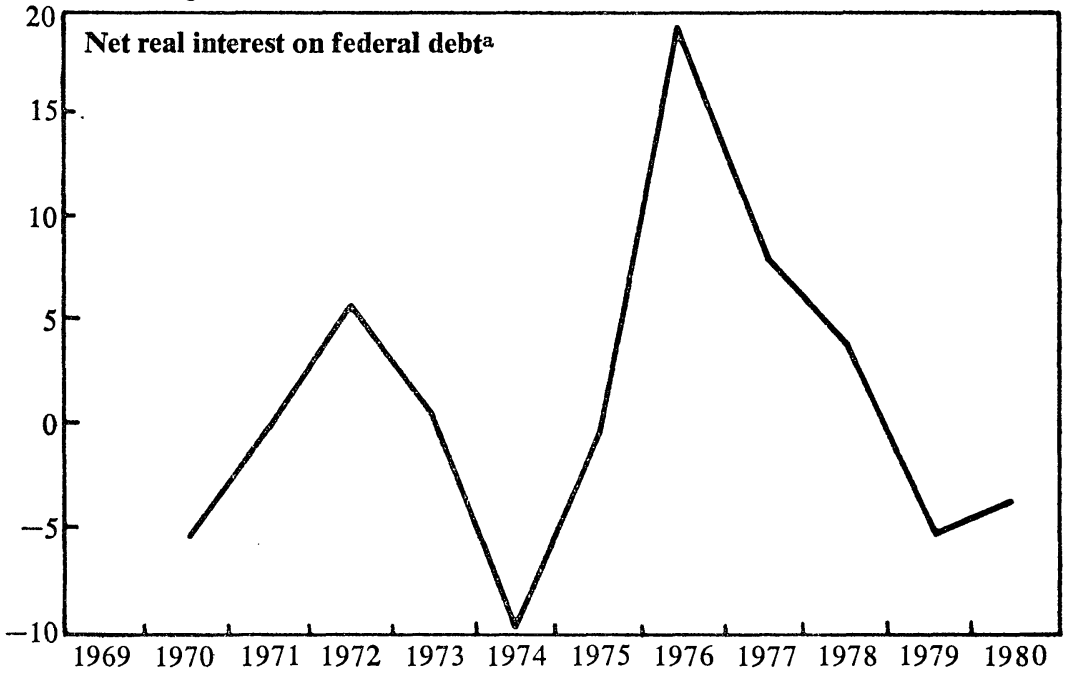

Sources: Government purchases of goods and services-Bureau of Economic Analysis, national income and product accounts; high employment federal deficit and potential GNP-Economic Report of the President, January 1978, pp. 55 and 84, and Economic Report of the President, January 1980, pp. 50 and 90; and net real interest on federal debt-The Budget of the United States Government, Fiscal Year 1979, pp. 477 and 487, and The Budget of the United States Government, Fiscal Year 1981, pp. 601 and 613.

a. The deposit of earnings by the Federal Reserve System was subtracted from the published series for the net interest on federal debt. Data are for fiscal years, and 1980 is an estimate. 
payments to holders (other than federal agencies themselves) on the assumption that nominal interest rates on the securities were the same as in the base year, 1972. Thus the series excludes the increased interest payments due to the rise in nominal rates associated with inflation since 1972, most of which is in real terms repayment of principal. This real interest obligation has grown only by 11.4 percent since 1969, while real GNP has risen 33.7 percent, and potential GNP, 36.8 percent. Federal debt has declined relative to the economy. Its rate of change, as pictured in figure 5 , has also been generally countercyclical.

Some trends in macroeconomic theory downgrade the importance of fiscal policies for good or ill. I do not refer just to the financial crowdingout propositions of Monetarism-1. A different source of skepticism is the proposition that current and planned consumption depends only on the present value of after-tax labor and property incomes, calculated over very long future horizons. ${ }^{25}$ Changes in taxes and transfers, it is argued, affect these long-run calculations very little, if at all, especially if they are only temporary. I think that this argument carries to unrealistic extreme the valuable insights of permanent-income and life-cycle models of consumption. It ignores the liquidity constraints that shorten the horizons of many consumers. It does not recognize the role of the government as an intermediary between households with different present and future taxand-transfer status, diverse liquidity positions and horizons, varying attitudes toward risk, and different intertemporal discounts and tastes.

Temporary and one-shot tax reductions and rebates are less stimulative than permanent cuts, no doubt. But they increase the liquid wealth of households with short horizons, who are likely to be especially numerous when the economy is depressed. Macroeconometric model simulations confirm the efficacy of the fiscal stimuli of 1975 , and even the temporary tax surcharges of $1968 .{ }^{26}$

Why not rely solely on monetary measures to promote recovery from recessions? Fiscal stimulus in the form of direct spending on goods and services or transfers and tax reductions directed to private agents with

25. Barro, "Are Government Bonds Net Wealth?" and Robert E. Hall, "Stochastic Implications of the Life Cycle-Permanent Income Hypothesis: Theory and Evidence," Journal of Political Economy, vol. 86 (December 1978), pp. 971-87.

26. Data Resources, Inc., "Fiscal Policy: The Scorecard Between 1962 and 1976," in Joint Economic Committee, Economic Stabilization Policies: The Historical Record, 1962-76, 95 Cong. 2 sess. (Government Printing Office, 1978), pp. 11-60. 
high propensities to spend can be a surer way of increasing aggregate demand. Private spending may respond only weakly and slowly to the favorable interest rate and credit climate that monetary policy can produce. Moreover, the monetary authority is generally unwilling to push hard on the string, fearing that the liquidity created will be troublesome later.

My review of recent fiscal policy underlines the fact that this is the terrain of macroeconomics where the gulf between perceptions of the general public and economists' doctrines is the widest. Probably the most popular diagnosis of inflation is deficit spending, and the most common recipe for relief is balancing the federal budget.

Economists know that stabilization policy is logically and operationally separable from the size and balance of the budget. The demand stimulus of a larger budget can be neutralized by various mixtures of taxation and monetary restriction, and the demand stimulus of a deficit-increasing tax reduction can be offset by monetary restriction. What is occurring today is a concerted campaign to exploit popular discontent with inflation to reduce the relative size of the public sector and to reverse the income redistributions effected by government taxes and transfers. These objectives are legitimate political agenda, which deserve debate and decision on their merits. But they have nothing to do with inflation, and monetarist-conservatives (there is no logical necessity for this almost invariable combination) should be the first to point this out. Monetarists once reconciled opposition to deficits with their "money-is-all-that matters" macroeconomics by alleging that political pressures force the Federal Reserve to print more money the larger budget deficits become. There is scant evidence for this effect these days.

\section{Demand Management at the Stagflation Impasse}

Even in happier times there were plenty of grounds for suspicion that price stability and full employment were incompatible objectives in modern capitalist democracies. Early in the game Abba Lerner, among others, pointed out that if Keynesian full employment were sustained the price level would be indeterminate, at the mercy of collective bargaining. ${ }^{27}$

27. Abba P. Lerner, "Money as a Creature of the State," American Economic Review, vol. 37 (May 1947, Papers and Proceedings, 1947), pp. 312-17. 
Sumner H. Slichter went further, observing that organized labor and central banks had switched roles, with unions determining the price level and central banks the volumes of output and employment. Graduate students of my generation told each other that of the three objectives-price stability, full employment, and freedom from wage and price controls-an economy like that of the United States could attain two at most.

Much of what we have learned since is simply the bad news that for "price stability" read "inflation rate stability" or more generally "stability of the expected path of prices," whatever its shape.

\section{THE UPWARD DRIFT OF THE "NATURAL RATE"}

The relationships of prices and money wages to output and employment, and of all these variables to demand-management policies, were the big questions in 1970 and remain so today. Within the consensus framework, the questions focus on the terms of the short-run Phillips curve trade-off, both on the location of the NAIRU and the shape of the curve relating accelerations and decelerations to deviations from the NAIRU. More far-reaching issues concern the validity of the framework itself and its reliability as a guide to policy.

One regularity of Brookings panel meetings and papers has been the relentless rise in numerical estimates of the full-employment rate of unemployment. ${ }^{28}$ Likewise the actions of policymakers reveal their implicit acceptance of ever higher normal unemployment rates. From 3 percent in the early 1950s, these explicit or implicit estimates of the natural rate seem to have risen successively to 4 percent in the 1960 s, 5 percent in the early 1970s, then 6 percent. In the early 1980s, it is easy to predict, the magic number will not be lower than 7 percent.

Why is the unemployment rate so high, and even higher, at "full employment"? How are such high NAIRUs to be rationalized by theorists who associate the "natural" rate with an equilibrium in which unemployment represents voluntary choice and efficient search? These questions have occupied much time at this panel and many pages of Brookings Papers.

28. Robert E. Hall, "The Rigidity of Wages and the Persistence of Unemployment," $B P E A, 2: 1975$, pp. 301-35, and "The Process of Inflation in the Labor Market," $B P E A, 2: 1974$, pp. 343-93; Michael L. Wachter, "The Changing Cyclical Responsiveness of Wage Inflation," $B P E A, 1: 1976$, pp. 115-59; and Robert J. Gordon, "The Welfare Cost of Higher Unemployment," BPEA, 1:1973, pp. 133-95. 
Explanations of the dismal trend fall in several categories.

1. The demographic composition of the labor force has shifted toward groups more prone to spells of unemployment between jobs or while entering, leaving, or reentering the labor force. Demographic shifts since 1965 can account for about a 1 percentage point rise in overall unemployment if each group is assumed to be permanently characterized by its specific 1965 unemployment rate. (On the other hand, such calculations omit demographic trends, notably those toward more educational attainment and toward stronger attachments of women to working careers, which would have opposite effects.) Essentially the same upward shift of the NAIRU emerges from the observed increase in the overall unemployment rate relative to the rates for prime workers whose unemployment relative to available jobs is thought to be crucial in wage determination, or from calculations of a wage-weighted unemployment rate. ${ }^{29}$

2. Government policies-unemployment compensation, welfare benefits, and minimum wages-have raised the reservation wages of the unemployed relative to their marginal productivity in employment. Here again the main issue is the empirical magnitude of these effects, a subject that several Brookings panel papers have addressed. ${ }^{30}$ My reading of them is that it would be hard to attribute more than a few tenths of a percentage point of unemployment to the changes in these institutions in this decade. In considering these policies as the cause of higher normal unemployment, it is relevant to remember that most of them were ex post responses to higher unemployment brought about by macroeconomic policies and events.

3. Normal rates of operation of capital capacity are now reached at higher rates of unemployment of labor than in the 1960s. In other words, the ratio of capacity to labor force has declined; recoveries encounter

29. These adjustments of unemployment rates are discussed in George L. Perry, "Changing Labor Markets and Inflation," BPEA, 3:1970, pp. 411-41.

30. For an analysis of how length of unemployment is affected by the availability of unemployment insurance, see Stephen T. Marston, "The Impact of Unemployment Insurance on Job Search," BPEA, 1:1975, pp. 13-48. Martin S. Feldstein examines the relative importance of temporary layoffs; see his "The Importance of Temporary Layoffs: An Empirical Analysis," BPEA, 3:1975, pp. 725-44. The effect of an increase in the minimum wage on other wages, the possibility of disemployment, and the distribution of family income are examined in Edward M. Gramlich, "Impact of Minimum Wages on Other Wages, Employment, and Family Incomes," $B P E A, 2: 1976$, pp. 409-51. 
bottlenecks earlier; labor productivity falls and markups rise when unemployment is still high. The stagflation of the 1970s discouraged capital formation, and businesses positioned themselves to survive cycles of higher average unemployment.

As for the shape of the short-run trade-off, Murphy's Law of macroeconomics assures us that it is an $L$ with the corner wherever we happen to be. Even less extreme nonlinearity has several significant implications.

One implication of Phillips curvature is that symmetrical cycles about a static NAIRU entail an accelerating drift. ${ }^{31} \mathrm{~A}$ stable inflation trend requires a higher average unemployment rate the greater the amplitude of fluctuations. The natural rate so corrected may have increased in the recent unstable decade.

A second implication of asymmetry, connected with the first, is that managers of aggregate demand who desire a stable inflation outcome will regard the risks of positive errors as greater than the risks of symmetrical negative errors. They will aim for higher unemployment the larger their uncertainties about private demand, about the marginal effects of their own measures, and about the position of the NAIRU itself. These uncertainties have been larger in the 1970s and so perceived by the authorities.

A third implication is that the aggregate Phillips curve will shift up in periods of high intersectoral demand and supply shocks. Frictional and search unemployment will be greater when microeconomic reallocations dictate higher turnover. This may well have happened in recent years. It is picked up in part by the dispersion variable that George Perry and others have introduced in wage equations.

I conclude that little of the alleged increase of the NAIRU has been credibly explained in terms of the labor market itself, as voluntary leisure disguised as unemployment, or rational job search, or friction, or persistent misinformation. For the most part, the apparent rise of the NAIRU merely describes but does not explain the chronic acceleration of inflation itself.

31. For example, support quarterly acceleration of inflation is $6\left(1 / U-1 / U^{*}\right)$, where $U$ is the unemployment rate in percent and $U^{*}$, the NAIRU, is 6 . This implies that a year of 7 percent unemployment will reduce inflation by 56 basis points. A $U-\bar{U}$ cycle of the pattern $0,1,2,1,0,-1,-2,-1,0$, and so on will accelerate inflation by 18 basis points a year if $\bar{U}$ is equal to $U^{*}$. To avoid such acceleration requires a mean $U$ some 25 basis points higher than $U^{*}$. This point was made in Martin Neil Baily, "Stabilization Policy and Private Economic Behavior," BPEA, 1:1978, p. 47. 
Given the unprecedented external shocks that have contributed to acceleration in recent years, it seems particularly gratuitous to describe the phenomenon by saying that the natural rate of unemployment has shifted up once again. One might instead interpret the absorption of real wage reductions in 1974-75 and 1979, with only modest acceleration of money wages, as evidence that labor markets were not very tight even at unemployment rates below 6 percent. It is true that in labor market equilibrium the trend of real wages, in terms of workers' consumption, must reflect the adverse trend in the terms of trade in industrial America. But that adverse trend has so far come in jolts, and until the dust settles nobody really knows whether any more unemployment, and if any how much, is permanently necessary to reconcile American workers to it.

It is hard to resist or refute the suspicion that the operational NAIRU gravitates toward the average rate of unemployment actually experienced. Among the mechanisms which produce that result are improvements in unemployment compensation and other benefits enacted in response to higher unemployment, loss of on-the-job training and employability by the unemployed, defections to the informal and illegal economy, and a slowdown in capital formation as business firms lower their estimates of needed capacity. Conceivably the economy is moving to ever higher rates of unemployment that impose no greater discipline on wage increases. After another half-decade of stagflation, the fear of acceleration is likely to be as great an impediment to expansion at 7 or 8 percent unemployment as it has recently been at 6 percent.

An observer uncontaminated by the economists' consensus, vintages 1970 and later, unburdened by the natural rate or the NAIRU, might interpret the evidence quite differently. He might even conclude that money wage acceleration depends mainly on the direction the economy is moving rather than on its level. This conclusion would be consistent with the old-fashioned aggregate supply curve in $p-Y$ space discussed above. It is supported by the scarcity of high-employment recovery periods when wage inflation was abating. The decelerations that have occurred took place largely during recessions. ${ }^{32}$

32. Of the thirty overlapping two-calendar-year periods from 1949 to 1979 , there are six in which the rate of wage increase fell while unemployment was also falling. These include 1952-53, during Korean wage-price controls, 1962-63 and 1963-64, the period of Kennedy-Johnson guideposts, and 1972-73, the period of Nixon controls. The other two are 1959-60 and 1976-77. There are seven recession biennia 
It is possible that there is no NAIRU, no natural rate, except one that floats with actual history. It is just possible that the direction the economy is moving in is at least as important a determinant of acceleration and deceleration as its level. These possibilities should give policymakers pause as they embark on yet another application of the orthodox demandmanagement cure for inflation. The recession may bring disinflation, though at a frustratingly slow pace. The cumulative impact of a long and severe recession may eventually break the present core inflation. But will the economy ever be able to recover without accelerating wages and prices once again? This heretical view has policy implications quite different from the standard consensus. It questions the permanence of disinflationary gains from restrictive demand policies. It raises the value of stability in real economic outcomes, unlikely to be achieved by stability of policy.

INERTIA, EXPECTATIONS, AND STRUCTURAL

INFLATIONARY BIAS

The original econometric versions of the accelerationist Phillips curve included as the augmentation term a distributed lag of past price or wage inflation rates, and either confirmed or assumed that the coefficients of the lagged variables added to unity. This augmentation variable, embodying lagged prices and wages, could be interpreted in two distinct ways. It could be a proxy for price or wage expectations, assuming these expectations are formed adaptively; because of this interpretation, equations of this specification were commonly called "expectations-augmented." It could represent the inertia of wage- and price-setting institutions: explicit or implicit contracts and patterns of emulation and catch-up.

The radically divergent policy implications of these two interpretations of the same statistical variable were only beginning to be appreciated in 1970. Today the distinction is the crucial issue in the controversy provoked by the new classical counterrevolution in macroeconomics (Monetarism-2)..$^{33}$ This became clear as soon as rational expectations replaced

when wages decelerated and unemployment rose. The only period when there was acceleration of more than 50 basis points while unemployment was rising was 1974 75.

33. Robert E. Lucas, Jr., "Econometric Testing of the Natural Rate Hypothesis," in Otto Eckstein, ed., The Econometrics of Price Determination, A conference spon- 
adaptive expectations in theoretical specification of wage and price determination. Then expected policies rather than past inflation histories were doing the augmenting, and those policies were thereby deprived of the power to influence real outcomes, employment, and output. But if lagged prices and wages belong in the equation in their own right, representing institutional inertia and disequilibrium adjustment, then the qualitative conclusions of the 1970 consensus still stand.

I shall not resume this debate here. In the last paper of his I heard and read, Arthur Okun did a characteristically marvelous job of enumerating those observed facts of economic fluctuations which are not consistent with the misperceptions-equilibrium theories of the new classical macroeconomists. $^{34}$

A battle of models is in progress concerning the extent to which, within the rational expectations framework, contractual inertia damages the strong policy-ineffectiveness propositions of the new wave of monetarists. ${ }^{35}$ Common sense suggests that systematic feedback policies, based on information subsequent to that available when contractual commitments were made, will work and will be stabilizing. This seems to restore the effectiveness of policies. But Monetarists- 2 then ask why rational parties do not make contracts covering in advance any contingencies to which the policy authorities could respond. The empirically relevant point is that actual contracts do not cover such contingencies; given that fact, no one has license to assume that the economy behaves as if they do. A reason that actual contracts do not cover contingencies, more specific than the practical difficulties of writing Arrow-Debreu contracts, is

sored by the Board of Governors of the Federal Reserve System and Social Science Research Council (The Board, 1972), pp. 50-59, and "Econometric Policy Evaluation: A Critique," in Karl Brunner and Allan H. Meltzer, eds., The Phillips Curve and Labor Markets, Carnegie-Rochester Conference Series on Public Policy, vol. 1 (Amsterdam: North-Holland, 1976), pp. 19-46; and Thomas J. Sargent, "Rational Expectations, the Real Rate of Interest, and the Natural Rate of Unemployment," $B P E A, 2: 1973$, pp. 429-72.

34. Arthur M. Okun, "Rational-Expectations-With-Misperceptions as a Theory of the Business Cycle," prepared for the American Enterprise Institute Seminar on Rational Expectations, February 1980.

35. For a review and discussion of the literature, see Bennett T. McCallum, "Rational Expectations and Macroeconomic Stabilization Policy: An Overview," prepared for the American Enterprise Institute Seminar on Rational Expectations, February 1980; and John B. Taylor, "Aggregate Dynamics and Staggered Contracts," Journal of Political Economy, vol. 88 (February 1980), pp. 1-23. 
that compensatory policies are expected. If so, failure of the authorities to carry them out would be a surprise that puts both parties in less preferred positions. Moreover, I would remind the model builders, neither unemployed workers nor future entrants to the labor force are able to make contracts with anybody.

I expressed doubt above that the drift of the "natural rate" can be regarded as an equilibrium phenomenon. The alternative explanation is that most of the time labor markets are not in market-clearing equilibrium, that the disequilibrium adjustments to excess demand and excess supply are asymmetrical, that wages are mainly determined between employers and their existing employees with attention to mutual long-run commitments and to the maintenance of parities with other firms and workers, that except in extreme cases of economic duress the availability of unemployed workers has little effect on those determinations. This account implies that the economy has a structural bias toward inflation, even toward the acceleration of inflation. The structural bias means that inflation stability is not the same thing as equilibrium, that inflation stability generally requires aggregate excess supply in amounts that depend on the severity of the microeconomic and macroeconomic shocks to which the economy is subject, that inflation stability does not have the properties of allocational optimality associated with equilibrium. ${ }^{36}$

To state the issues in an overly simple but instructive way, there are two interpretations of U.S. inflationary history since 1965. One blames mistaken demand-management policies-they aimed at overfull employment, accommodated too readily existing inflation and inflationary shocks, intervened too promptly and energetically to arrest recessions and speed recoveries. ${ }^{37}$ According to this thesis, correct policies can bring price stability plus realistically full employment.

The other interpretation depends on the view that the price- and wagesetting institutions of the economy have an inflationary bias. Consequently, demand management cannot stabilize the price trend without chronic sacrifice of output and employment unless it is assisted, occasionally or permanently, by direct incomes policies of some kind. According to this second thesis, there is little hope that monetary and fiscal disinflation alone will cure the current stagflation.

36. I discussed these points in $1 \rightarrow$ "Inflation and Unemployment," American Economic Review, vol. 62 (March 1972), pp. 1-18.

37. See William Fellner, Towards a Reconstruction of Macroeconomics: Problems of Theory and Policy (American Enterprise Institute, 1976). 
I believe that, while the first interpretation of events since 1965 contains important elements of truth, especially for the 1966-69 period of excess demand, it is very difficult to reject the hypothesis of structural inflationary bias.

But why is there a break in the postwar history of inflation around 1965 ? On the first interpretation this is easy to explain by the acceptance of Keynesian demand policies in the early 1960s. The second thesis must explain why the alleged structural bias did not generate more inflation before 1965 .

The 1950s began with a successful application of wage and price controls during the Korean War. Thanks to these controls and to an austere fiscal policy, the speculative commodity price boom at the beginning of the war had no lasting inflationary effects. When the controls were removed, prices and price expectations were stable, with unemployment at 3 percent. There were three recessions in the decade of the 1950s. The recovery between the first and second took the inflation rate for gross business product as high as 5 percent, although unemployment barely edged below 4 percent. The succeeding recessions, responsible for the adage that it takes two recessions to expunge the inflationary legacy of one boom, left the Kennedy administration in 1961 with 7 percent unemployment and a 1 percent inflation rate. The recovery of 1961-65 raised inflation only to 2.5 percent while reducing unemployment to 4 percent. However, this was done with the help of the wage-price guideposts and of active if informal interventions by the federal administration in key wage bargains and pricing decisions.

There were other favorable factors that did not persist after 1965 . The flexprice sector was generally neutral or counterinflationary in this period. Farm prices fell precipitously from 1951 to 1957 and were quite stable until 1965. The relative price of energy declined slightly. The country benefited from cheap imports from Europe and Japan; the overvaluation of the dollar hurt the U.S. net reserve position but was not reflected in dollar import prices while the exchange rate was pegged.

In summary, it can be argued that the structural bias toward inflation was there all along, but was held in check by a combination of frequent recessions, episodes of wage-price controls and guideposts, and favorable price inputs from flexprice and foreign sectors.

If the economy has an inflationary bias, if the NAIRU consists in significant proportion of involuntary unemployment, what can and should be done about it? The Galbraithian solution, permanent wage and price 
controls over the fixprice sector, entails all the familiar allocational inefficiencies. Probably it does not even solve the basic problem, namely to permit the economy to operate at higher rates of utilization without chronic inflationary pressure. The pressure would still be there bumping against the controls, and they would not survive.

The more fundamental solution is to diminish the asymmetry of wage and price response to excess supply and demand. This involves increasing the power of the economically disenfranchised outsiders, whose availability for work has so little impact on the wages paid the insiders or the prices set by their employers. A litany of procompetitive reforms has long been dutifully included in discussions of the trade-off dilemma. ${ }^{38}$ It is a familiar list: antitrust; open union membership; labor market policies, among them training, retraining, and relocation; reform of unemployment insurance, public assistance, and minimum wage; repeal of DavisBacon and a host of other sacred cows. These things just do not get done.

A different approach is to use controls to mimic competitive behavior, for example to prevent wage increases by firms whose employment is decreasing at a time when qualified job seekers are available to them. Collective bargaining is carried out by the sanction of national legislation, and the public has the right to restrict the contents of contracts achieved under governmental protection. In similar vein, legal recognition could be withdrawn from collective bargaining contracts lasting more than one year. The quid pro quo from business would be the avoidance of price increases at times of declining sales and rising excess capacity. At the very least, such behavior should be a prima facie cause for attention from the antitrust division. The purpose of these proposals is to strengthen sectoral and economy-wide disinflationary responses to slack, diminishing the asymmetry that leads to inflationary bias.

\section{WHERE DO WE GO FROM HERE?}

In figure $6, \mathrm{I}$ follow an old Brookings panel precedent of mine by presenting a simulation of the paths of unemployment and price inflation implied by a relentless policy of gradual monetary disinflation. ${ }^{39}$ The

38. See Economic Report of the President, February 1970, pp. 70-71; Economic Report of the President, February 1971, pp. 78-82; and Robert W. Crandall, "Federal Government Initiatives to Reduce the Price Level," in Arthur M. Okun and George L. Perry, eds., Curing Chronic Inflation (Brookings Institution, 1978), pp. 165-204.

39. James Tobin, "Monetary Policy in 1974 and Beyond," BPEA, 1:1974, p. 230. 
Figure 6. Simulated Effects of Monetary Disinflation on Unemployment and Inflation, 1980:1-2000:1

Price inflation

(annual rate, in percent)

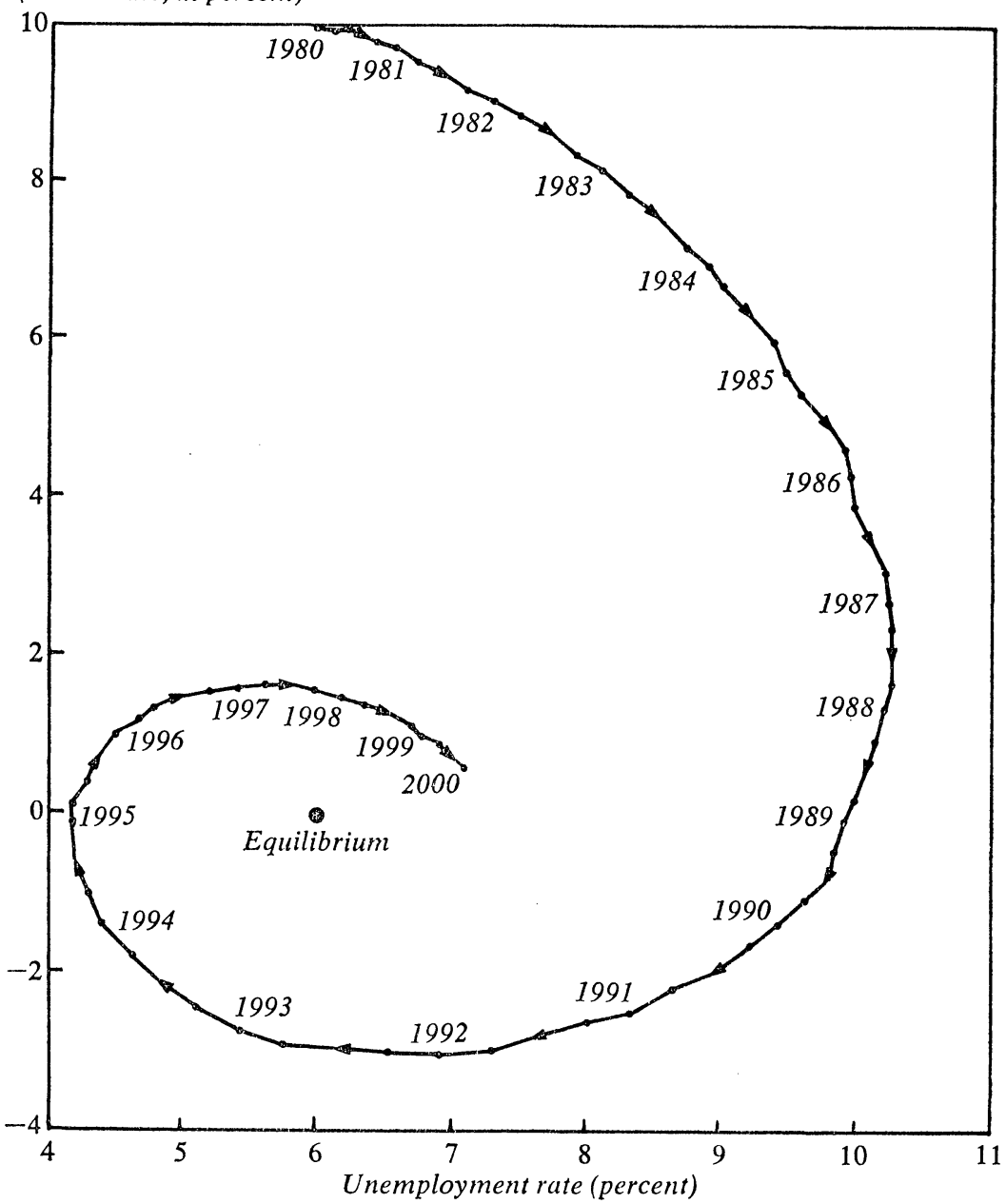

Source: Derived by the author. See text discussion.

policy is a specific version of the popular orthodox remedy for current inflation in the United States. The economy to which this policy is applied is a stylized version of the consensus view, with structural specifications and numerical coefficient values that embody conventional econometric consensus based on U.S. time series. 
The story is as follows: beginning in 1980:1 the government takes monetary and fiscal measures that gradually reduce the quarterly rate of increase of nominal income, $M V$. It is reduced in ten years from 12 percent a year to the noninflationary rate of 2 percent a year, the assumed sustainable rate of growth of real GNP. The inertia of inflation is modeled by the average of inflation rates over the preceding eight quarters. The actual inflation rate each quarter is this average plus or minus a term that depends on the unemployment rate, $U$, relative to the NAIRU, assumed to be 6 percent. This term is $\left(6 / U_{-1}-1\right)$. It implies a Phillips curve slope of one-sixth a quarter, two-thirds a year at $U=6$ and has the usual curvature.

At the start, real GNP is growing at its sustainable rate of 2 percent and unemployment is 6 percent. But the inflation rate is 10 percent. The development of unemployment is modeled by Okun's Law with a coefficient of 2 .

Figure 6 shows that in this simulation a recession lasts until 1987, when unemployment reaches a peak of 10.3 percent and inflation has been reduced to 2.3 percent a year. In 1990 , unemployment is 10.0 percent, and prices are stable.

The simulation illustrates another point. Steadiness in monetary policy, as registered in dollar spending on GNP, does not mean stability in economic outcomes. The cycle in figure 6 is damped, but it is wasteful and unnecessary. Clearly it would be preferable, and possible, to aim directly for the equilibrium (zero inflation, 6 percent unemployment) before the inflation rate crosses zero.

This is not a prediction! It is a cautionary tale. The simulation is a reference path, against which policymakers must weigh their hunches that the assumed policy, applied resolutely and irrevocably, would bring speedier and less costly results. There are several reasons that disinflation might occur more rapidly. When unemployment remains so high so long, bankruptcies and plant closings, prospective as well as actual, might lead to more precipitous collapse of wage and price patterns than have been experienced in the United States since 1932. Moreover, the very threat of a scenario like figure 6 may induce wage-price behavior that yields a happier outcome. A simulated scenario with rational rather than adaptive expectations of inflation would show speedier disinflation and smaller unemployment cost, to a degree that depends on the duration of contractual inertia, explicit or implicit. 
One advocate of a policy like that of the simulation, William Fellner, argues that its effectiveness will be greatly enhanced if the intentions of the government are made credible to the public at the outset. ${ }^{40}$ Consequently, he proposes that the government commit itself, ostentatiously and irrevocably, to the scheduled disinflation of monetary demand, whatever the outcome in employment, production, and profits. I agree that, if the authorities do in fact intend to follow such a schedule, they should make their intentions crystal clear in advance. I agree, too, that if the threat could in fact be made credible, the disinflationary response would be faster than implied by the conventional Phillips curve coefficient used in my simulation.

The question is how much. One obvious problem is that a long-run policy commitment can never be irrevocable, especially in a democracy. Important economic groups will not find it wholly credible, and some will use political power to relax or reverse the policy. Even assuming credibility and understanding by private agents, their responses are problematic. In the decentralized but imperfectly competitive U.S. economy, wage and price decisions are not synchronized but staggered. It is hard to predict how individual firms, employees, and unions will translate a threatening macroeconomic scenario into their own demand curves. If each group worries a lot about its relative status, each group will decide that the best strategy is to disinflate very little.

Finally, the problem is not simply unwinding an unpalatable inflation resulting from past monetary mistakes. The simulation reported in figure 6 does not allow for further inflationary shocks from OPEC, dollar depreciation, world shortages, or other events not now foreseen. Any of these could delay or prevent disinflation and raise the real costs of nonaccommodative policies, whether accompanied with a credible threat or not. It is far from certain that society has consensus on how the burdens of real economic reverses should be shared, or even on how such questions should be decided. An economic path anything like figure 6 will probably be politically and socially divisive.

For these reasons, I think it would be recklessly imprudent to lock the economy into a monetary disinflation without auxiliary incomes policies. The purpose of these policies would be to engineer directly a deceleration

40. William Fellner, "The Credibility Effect and Rational Expectations: Implications of the Gramlich Study," BPEA, 1:1979, pp. 67-78, and Towards a Reconstruction of Macroeconomics. 
of wages and prices consistent with the gradual slowdown of dollar spending. Macroeconomic policy and wage-price guideposts or controls would be concerted. Instead of issuing a monetary threat to everyone in general and to no one in particular, the government would seek the consent and cooperation of organized labor and business in a five- to ten-year program to eliminate inflation at minimal cost in employment, production, and investment. The most promising incomes policy is to use tax-based incentives for complying with a sequence of gradually declining guideposts. ${ }^{41}$

This combination of controls and demand management would avoid the major pitfalls that have discredited previous episodes of controls. It would not try to restrain wages and prices in face of excess demand. At a macroeconomic level, this would be avoided by the consistent scheduling of monetary disinflation and guideposts. At a microeconomic level, compliance with guideposts would be induced by tax-based rewards and penalties, leaving individual firms flexibility to respond to the circumstances of particular markets. At the time the policy was ended, there would be no reason for anyone to be committed to or to expect wage or price increases greater than the final guideposts. Macroeconomic demand policy would be consistent with the actual inflation rate at the time.

At present there is no social consensus to support the combination of demand management and incomes policy just sketched. Yet public opinion polls again and again report latent majority support for controls, the direct remedy for inflation to which ordinary citizens instinctively turn. It will take more political leadership than the United States has seen for a long time to transform those sentiments into consensus for an effective policy. The importance of the project extends beyond the conquest of inflation to the real problems of resource allocation and wealth distribution that confront and divide us.

The people say that inflation is problem number one, and because they say so it is. "Inflation" has become the national obsession, the catchall scapegoat for individual and societal economic difficulties, the symptom that diverts attention from the basic maladies. Episodic efforts to control it, and constant anticipation that they will occur but achieve no

41. See Okun and Perry, eds., Curing Chronic Inflation. For an elegant alternative with the sane properties of flexibility, see Abba P. Lerner, "A Wage-Increase Permit Plan to Stop Inflation," in ibid., pp. 255-69. 
more than transient success, severely damage the economy's real performance and future potential.

Yet despite the repeated rhetoric of firm resolution, the political leadership of the country does not adopt or even propose an effective program. This is partly because the economic and political establishment is beguiled by simplistic diagnoses and remedies, for which the economics profession bears no little responsibility. The government did it all-by spending too much, taxing too much, borrowing too much, and printing too much money. Let the government turn off all those spigots and there will be no more inflation.

It is not possible to do the job without effective wage and price controls of some kind. Demand management cannot do it alone. Without the leadership to develop a national consensus to face that truth, the prospects are for more stop-go, more muddling through. There could be worse prospects, and probably they include determined but unassisted monetary disinflation. 


\section{Comments by Edmund S. Phelps}

The two most important problems to be faced in economic stabilization are easy enough to identify: first, are there any ways to break out of the present pattern of double-digit growth in money-wage rates? If so, what is the set of workable schemes from which to choose, and which scheme (or mix of schemes) entails the least social cost? Second, assuming it is possible to extricate the U.S. economy from the present morass, can macroeconomic policy be conducted in the future in a way that will avoid (or at least minimize the risk of) falling again into the same predicament? If so, what sorts of macro policies are in the set of safe choices?

The difficulty is in reaching agreement over the answers to these questions. Perhaps the United States and other countries will have to experiment with trial medications until successful ones are demonstrated and their relative costs estimated. The difficulty is greater than in the 1930s because then there was the distinct possibility that something would turn up-that gloom about the profitability of investment would dissipate as mysteriously as it had begun. The difficulty now is not a possibly transitory parametric shift but rather is an endogenous malfunction that will not disappear by itself.

Consider the first problem. The revival of interest in fiscal economics, especially the effects of taxation on the supplies of labor and saving, has led to the belief that scientific tax reform might make a contribution to the reduction of the current rate of price increase.

In the simplest monetary model, where all money-wage rates are set (or otherwise determined) synchronously, an increase in the supply of laborfor example, engineered through selective cuts in marginal tax rates at the top wage-income brackets-would slow the rise of the equilibrium moneywage level only after it had somehow reduced the expected wage level. (The equilibrium level is defined as the level resulting when demand makes the actual wage level equal the expected level and thus makes the 0007-2303/80/0073-0078\$01.00/0 @ Brookings Institution 
employment level equal to its equilibrium level.) Such an increase in labor supply could dampen these expectations by first creating a disequilibrium marked by increased unemployment with wages lagging behind expectations, or directly by causing a revision of wage expectations in anticipation of the increase in the supply of labor. The former disequilibrium process means a temporary surge of joblessness triggered from the supply side, which is not much better (with respect to social welfare) than a bulge of unemployment engineered from the demand side: some young job seekers would lose out in competition with those spurred by tax reform to make an extra dollar.

In a minimally realistic model in which wage rates are set in staggered fashion for a nonnegligible duration, even the hypothesis of correct wage anticipations ("rational expectations") would not prevent a temporary rise of unemployment. The additional job seekers could bid down the average money-wage only gradually, as successive wage-rate commitments of firms came up for revision, so the extra lump of labor supply could not instantly be absorbed-not in any equilibrium (correct expectations) scenario. Nevertheless, this temporary unemployment has a smaller involuntary component than that typically produced by a demand-side slump. Severely inflationary times may thus be propitious for supply-side reforms, even though the accompanying monetary policy will not immediately create an extra job for every extra job sought-not if $i t s$ aim is ending the excess inflation.

Likewise, it might be possible to introduce subsidies for the employment of low-wage workers at this time of high inflation. The resulting rise of job seeking would eventually slow down the spiral of rising moneywage rates, provided that the central bank does not rush in to accommodate the increased labor supply with the creation of an equal number of new jobs at existing money-wage rates.

The other focus of supply-side economics has been on the supply of saving, which is the next generation of workers' capital stock in the stylized overlapping-generations model of life-cycle saving. If only a permanently higher rate of growth of the capital stock could be engineered through tax reform and thus a permanently lower rate of price inflation achieved at the old rate of wage inflation! But the Solow-Swan model teaches us that, over that wide range of cases where a natural rate of growth exists, any excess of capital's growth rate over that of technologically weighted labor must vanish in the limit. Going to the other extreme, consider the dis- 
inflationary effect, if any, from a finite-lived episode of extra saving and investment.

A familiar claim is that the forward momentum of money-wage rates is attributable largely to their implicit index-linkage to the cost of living. Suppose that 100 percent indexation to the price level is the whole wage story: thus wages rise at 10 percent a year because prices are rising at that rate. It is then argued that if an annual growth rate of productivity of 10 percent could be obtained for just one year, the inflation rate would shortly vanish. In the first year, prices would be flat, thanks to the productivity rise. In the next year, wages would not rise and so prices would remain flat, and so on indefinitely.

This arithmetic is usually classified as good news; the bad news is that engineering the 10 percent productivity jump may be hard. But the message is perhaps too good to be true. Consider a rise of productivity spread over two years, say 6 percent the first and 4 percent the next. The second year will see wages rising at only 4 percent because inflation during last period fell to that rate (10 percent minus 6 percent), and prices will have flattened out because the remaining productivity rise will offset that rise of wage rates ( 4 percent minus 4 percent). In general, productivity growth of 10 percent spread over $N$ years will achieve a flat price level by the $N$ th year. So, unless technological progress has finally petered out, it is just a matter of waiting patiently for the cumulative growth of productivity during the 1980s and 1990s to reach 10 percent in order to see the end of the inflation! Fresh supply-side reforms are not needed-they would merely serve to hasten the disinflationary process.

The above exercise takes place at a fixed unemployment rate. The model might be extended by adding an equation making the ratio of the current period's wage level to the last period's price level, or, more familiarly, the rate of change of that ratio, a Phillips curve function of the current unemployment rate. The model could then be estimated. I wager that it would fit very well! Perhaps it is even the right model for Germany, always remembering that its unemployment is located in Turkey. But it is certainly measurement without theory: the theories that imply 100 percent indexation are unacceptable in important ways-I refer to state-contingent contract theories-and there are reasons why rational contractors would shun 100 percent escalation. For that matter, quite a lot of employment is not contractual at all because it is a short-term, free-lance business of doing a closed-end job-pickup work. 
If the model is modified by assuming fractional indexation to the price level, then, assuming the central bank holds constant the unemployment rate, the one-shot 10 percent productivity gain achieves only a transient lessening of the inflation rate, just as an adverse supply shock achieves a transient worsening. The long-run effect of supply-side therapies, therefore, is the same as if there were no index linkage to the cost of living.

Because of these long-term characteristics, I believe that it is not very far wrong to neglect indexation to the price level altogether. For purposes of policy planning, I still recommend the sort of staggered wage-setting model that I began using in my own thinking way back and have elaborated upon a couple of times in recent years. At least I would be inclined to take a chance on the applicability of that kind of model. In the hand of a master econometrician like John Taylor who made the model operational, it does very well indeed. I have that type of model in mind in the remainder of my remarks.

Is there a good word to say for price or wage controls? Maybe it is like putting an ice pack on a patient with a high fever to stop the fever. It buys time until something fundamental is done. Controls are not fundamentalthey are like putting out the yellow flag at an automobile race: there is no permanent effect because the cars all keep their relative positions until the yellow flag is raised again, whereupon they go back to racing as they would have before. In principle, controls plus judicious exceptions could straighten out the problem in two years or so. In practice, nobody could be confident of devising and running a program with much chance of success. More radically, an autocrat could impose, say, Dutch or Swedish pay scales at any desired exchange rate until Americans could not remember their accustomed place in the old wage structure. Maybe that would end the inflation, though it would certainly cause many bankruptcies and dismissals. It would require a national union of sorts to monitor workers and employers that may try to cheat. Such radical surgery is a last resort.

That seems to leave the U.S. economy needing demand-side measures to bring down inflation, with or without help from some of the other measures considered earlier. Here I wonder whether it would be useful to preannounce to the public a target time-path of some familiar moneywage series and emphasize how quickly the target path flattens out-becoming virtually level in about a year if complete cessation of wage inflation should be the objective. So merely "catching up" fully with the latest 
and therefore highest wage rates-let alone "going ahead" as practiced in the past-is a bit risky because those wage rates are now out of line and will not become the standard for at least a year (when all other wages have had the opportunity to catch up) provided that, in fact, other wages will not "go ahead" during the year. Success depends on instilling fear that the central bank will push unemployment a year hence to whatever level is needed to assure that those wage rates, the ones revised only a year or so from now, will be held to the target. At the same time the money supply must be permitted to rise early in the program to accommodate the justified and prescheduled catching up.

All this is chancy without the benefit of a "demonstration recession" to create assurance that "going ahead" with one's wages would be too risky. Some luck would be needed together with skill. Such a strategy might do poorly from the beginning with wages not decelerating on schedule, causing the central bank to tighten policy with somewhat unforeseeable consequences for the magnitude of the rise of the unemployment rate. A discretionary wage authority might look attractive at that point. But the wrong wages might be restrained, with a consequent widening of the wage gaps requiring catch-up increases in the future.

The complete cessation of wage increases-an end to the basic rate of wage inflation-seems disproportionately risky and might block even partial success. On the other hand, a target of 9 percent wage inflation might also be costly to achieve, and the public would demand to see the gain. Some measures of inflation might show an increase. So a more ambitious target may be preferable.

The second key problem today, which seems of lesser urgency, is how to hold the fort once it has been recaptured. I say seems less urgent because if the government is unwilling or unable to hold the fort, no one is going to expect the harder feat of retaking it. The answers here may be crucial to the credibility of the government's disinflationary program.

The fixed-throttle monetarism of 3 to 6 percent growth of the money supply annually certainly is no safeguard these days against substantial inflation. The velocity of money has gone from random walk to random sprint. Perhaps 10 percent wage growth will someday be possible on 6 percent money growth.

If the ultimate end of monetary policy is stabilization of the money wage around some trend-path, there surely exists a feedback policy that would 
perform better than the fixed throttle-better against most shocks most of the time. When the fire of wages is low, why not throw on more monetary coal?

There seems to be little doubt that poor control (with firm intentions) is much less important than lack of self-control at those times when the basic inflation rate is so low that the risk of boom conditions is attractive to the government. That willingness to risk boom and an upward ratchet in the basic inflation rate is not unreasonable when that rate is less than optimal. But some governments tend to overdo it. The painful lesson that the country is learning now may serve to increase confidence in future governmental willingness to contain inflation. 


\section{Comments by William Poole}

In 1967, three years before the Brookings panel first met, the government's managers of aggregate demand were stimulating an economy experiencing overfull employment and the excess demands associated with the Vietnam War. The unemployment rate was below 4 percent and the inflation rate was rising. Five years later, in 1972, the demand managers were again stimulating the economy. The unemployment rate, at about 5.5 percent, fell and inflationary pressures were about to blow the lid off wage and price controls. Four years ago, in 1976, the government was in the early stage of what turned out to be a three-year program of stimulating an economy that was already recovering from the worst recession since the Great Depression and that had been on a course toward lower inflation rates.

The thrust of my first paragraph is exactly opposite to James Tobin's first paragraph; neither paragraph is adequate. My major problem in discussing this paper is exactly that it seems unbalanced. Tobin discusses many issues; rather than produce a catalog of responses, as a former Federal Reserve staff member, I will discuss the tone and feel of this paperits balance and perspective. The paper's overall tone, as I read it, is that inflation is a problem only insofar as it is likely to lead to policies that generate unemployment. In the discussion of Monetarism-1 and -2 the overall tone seems to be that there is not a thread of truth in either doctrine. My job as a discussant would have been much easier if Tobin had written less about why he does not accept certain propositions that he labels extreme. I have no difficulty in agreeing with him that certain coefficients are not precisely zero or that some monetarists have claimed too much, but discussion is difficult when the debate is cast in these terms. Rather than argue about extreme cases, I will discuss several areas in which my beliefs concerning orders of magnitude differ significantly from Tobin's. 
I agree completely with his comment at the beginning of the paper that the inflationary components of the expansions in 1971-73 and 1975-79 were unexpectedly and distressingly large. The key issue, though, is whether there was something wrong with the expectations. There are two aspects to this question. There may be something wrong with the macroeconomic theory on which these expectations were based or with expectations about how government policy variables and other variables exogenous to the models would evolve.

Tobin emphasized the role played by nonpolicy exogenous shocks. I believe that emphasis is misplaced. From a Keynesian point of view, policy is supposed to offset shocks, or at least to be robust in response to them. Instead, policy during the 1970 s has amplified shocks. More importantly, I am convinced that, with the exception of the initial OPEC oil price increases in late 1973 and early 1974, to a great extent these shocks reflect endogenous responses to inflation rather than exogenous disturbances. Tobin himself mentions that, for agricultural and other raw commodities, supply is price-inelastic so that prices for these items are very responsive to demand.

At the heart of this matter is an incomplete understanding of the real effects of inflation. Ten years ago most economists emphasized the goal of stable rather than zero inflation, in the belief that the costs of inflation were due entirely to its being unanticipated. All that was necessary, it was thought, was to maintain a stable rate of inflation so that there would not be costly mistakes in expectations.

Few can have confidence in this analysis any longer, at least as it applies to a policy horizon of five to ten years. It may well be that the economy can adjust to any stable long-run rate of inflation, generating a real equilibrium that is largely independent of the rate, but such a textbook view is surely not the environment in which macro policy decisions must be made over the relevant policy horizon.

For reasons that are not well understood, it appears that higher average inflation rates are associated with less stable inflation and, therefore, larger errors in expectations. Moreover, it is now clear that institutional adjustments to inflation are slow; even after fifteen years of inflation the economy has not produced all the institutional adjustments necessary to permit an unchanged real equilibrium.

One of the most significant problems is surely the nonneutrality of the tax system. The U.S. tax system-and especially the federal tax system- 
has diverted spending away from business fixed investment and toward residential housing and consumption. The heavy taxation of business capital due to original cost depreciation and the taxation of nominal interest and nominal capital gains was there for all to see fifteen years ago, but few predicted that those distortions would be important. Inflation was discussed in terms of simple models in which the real equilibrium would be largely unaffected by inflation. Many argued confidently, for example, that common stocks would be a hedge against unanticipated inflation.

I do not know how the distortions of the tax system under inflationary conditions were missed, or why it was assumed that the tax system would be altered and effectively indexed against inflation, but the fact is that most analysts did miss this major nonneutrality in the inflation process. To a great extent, I suppose, inflation was discussed in terms of what could happen if institutional adjustments occurred rather than what was likely to happen. Of course, major institutional adjustments to inflation have occurred; I am simply emphasizing that many adjustments required for neutrality in the face of anticipated inflation have not occurred.

As a result of this experience, many probably think that the consequences of inflation are not well understood. If matters that are now so obvious as the nonneutrality of the tax system could cause surprises, ongoing inflation may well hold other nasty surprises. I fear that the problem may be much deeper than a simple matter of slow institutional adjustment; adjustment may remain incomplete for fundamental reasons we do not now understand.

There is no mystery whatsoever about the trend rate of inflation. Secular inflation is a monetary phenomenon not in the tautological sense of being a function of $M V$ but in the refutable sense of being a function of $M$. There are problems in defining the money stock: some of them stem from the absence of a well-developed theory to use in constructing the real world counterpart to the "money" of economic theory; others stem from easily understood, though empirically difficult, issues of responses of markets to the prohibition of interest on demand deposits and the Regulation $\mathrm{Q}$ ceilings, which limit interest on time and savings deposits. These ambiguities produce problems with magnitudes, but there is no definition of the money stock, narrow or broad, new or old, that does not provide the same answer qualitatively.

The problems with the monetary data do not deserve to be singled out. 
There are problems of exactly the same kind, and in many cases even greater problems with price indexes, unemployment data, real GNP measures, and government spending and revenues. An eclectic Keynesian struggling with the distinction between government spending on goods and services and spending on transfers, or with the proper treatment of loan guarantees and of so-called tax expenditures, or with estimates of fullemployment revenues and expenditures, should go slow in building a case against monetarism on the basis of conceptual ambiguities in the data surrounding the definition and measurement of money.

The mysteries do not involve the monetary nature of inflation but rather the real effects of monetary disturbances and the nonneutralities of anticipated inflation discussed earlier. With regard to the debate between those who hold Keynesian views and those who hold the new classical views, I find myself in many respects an agnostic. I agree with Tobin, with Arthur Okun, and others that there are numerous empirical observations that do not seem consistent with the new classical models.

It is totally unsatisfactory, though, to believe that the purely descriptive notions of "stickiness," "momentum," "inertia," "inflationary bias," "wage norm," and so forth have any obvious policy relevance. There is persistence, but the policy relevance of the phenomenon depends on its causes. I have to believe that genuinely forward-looking expectations are important, but that is not to say that only expectations are important. The new classical view may pay too much attention to expectations, but Tobin pays too little. It is important to know whether wage persistence is caused by persistence in expectations or by sluggish and lagged adjustment to disequilibrium; observation of persistence alone is not enough.

My suspicion is that the basic difficulty lies in the lack of a theoretical model integrating expectations behavior with the informational role of the price system. From the beginning of the first course in economics, economists have been taught that the price system is an extraordinarily efficient transmitter of information. I do not need to know that the supply of good walnut is declining to reduce my purchases of walnut furniture; I need only react to the higher price of such furniture. While much of my behavior is based on expectations, much of it is only reactions to observed prices. Adaptive expectations capture the flavor of this idea of economic responses to observed prices.

The walnut market may behave as if I processed all available information because specialists in this market hold inventories of trees and 
lumber. But if there is a fire in a walnut forest, should the price of walnut lumber be expected to adjust immediately to its new equilibrium level? I can believe that the price jumps to a level that is an unbiased estimate of the new equilibrium, but I cannot believe that further trading, and the effects on prices of that trading, provides no information whatsoever about the effects of the forest fire on the new equilibrium price.

In Richard Muth's rational expectations model, price is determined on the assumption that everyone knows supply and demand elasticities. Observation of prices and quantities plays no role in the estimation of elasticities. Demand and supply could be written as functions of the exogenous disturbances driving the model rather than as functions of price; the auctioneer could just as well call out disturbances as call out prices.

The models pioneered by Robert Lucas do provide for prices to have an informational role, but not of the type I have been discussing. Economic agents extract from local prices information about aggregate disturbances, but only given knowledge of the variances of relative and aggregate disturbances. Surely this knowledge must itself be derived in part from observation of actual prices. But forecasts must also depend, as Muth emphasized, on information besides that derived from price observations alone.

Tobin offers two "overly simple but instructive" interpretations of what has happened to the U.S. economy. The first blames demand-management policies, and I assume he would not mind if I added to that view that expectations of future demand-management policies have played an important role in labor market behavior. "The other interpretation," Tobin writes, "depends on the view that the price- and wage-setting institutions of the economy have an inflationary bias." I cannot accept any part of this other view because it is merely a description and not a proposition that is subject to refutation by marshaling data to test specific hypotheses.

There are a large number of other issues discussed in Tobin's paper, and I want to comment very briefly on a few of them. Although I do not share Tobin's apparent lack of concern over the size of the federal budget, I absolutely agree that the inflation issue and the budget issue should be kept distinct. Neither the size of the budget nor the size of the deficit has much to do with inflation, taking the Federal Reserve's monetary policies as given. And I do not believe that deficits have had much to do with those policies.

Supply-side issues are important, and I am sure that disincentives and 
distortions from taxes and subsidies have hurt the economy. I do not know whether Martin Feldstein overestimated these effects; but I agree that Arthur Laffer has.

Because I believe that expectations effects are important, I obviously favor steady and predictable money growth. But I fail to understand Tobin's argument that the Federal Reserve should announce target ranges for the next year or two or three-not for the money stock but for nominal income growth, or for the real and price parts of nominal GNP.

Announced targets have two purposes: to promote better private decisionmaking and to provide a standard of accountability for public officials. Although the terminology is awkward, a distinction needs to be made between targets for instruments, such as the money stock, and targets for targets (or goals), such as employment and inflation.

A factual issue is important. At the current state of knowledge, how closely can the Federal Reserve control, say, nominal GNP? Because I believe that year-by-year the income velocity of money is rather volatile and difficult to predict - a view that Tobin shares-in my view, the Federal Reserve does not know how to control annual GNP closely enough, so it is not reasonable to hold that authority responsible for annual GNP fluctuations.

The national administration already announces targets for targets, and I do not believe that these announcements provide much information. Precisely because there is so little consensus on macroeconomic theory, any of a number of different policies may be advocated as being not only consistent with the targets but also as absolutely necessary to their achievement. Economists will argue the matter ex ante and ex post, and only on those rare occasions when all agree will it be possible to show that GNP missed its announced target range because the policymakers made a mistake. How can public officials be held accountable when the experts are divided as to what the officials should have done?

Because I know that the Federal Reserve does not know how to hit GNP targets, its announcement of such targets would provide information to me only insofar as it helped me to predict money growth. My moneygrowth predictions would depend on the announcement of GNP targets in a very complicated way. I would have to consider the economic views of the chairman of Federal Reserve, the members and staff of the Federal Open Market Committee, and the extent to which the announcements reflected pure public relations. Idle announcements are easy when failures 
to hit targets can be readily attributed to shocks and other factors beyond Federal Reserve control. I have no doubt that those in politically sensitive positions, whether or not trained as economists, will from time to time succumb to the temptation to make promises they do not know how to keep, or even intend to try to keep; but I would like to keep such behavior to a minimum by restricting promises to variables clearly under that authority's control.

The Federal Reserve does have the technical means to control the money stock quite accurately. While I believe it is unreasonable to hold the Federal Reserve accountable for every percentage point of inflation in 1979, I can hold it accountable for permitting money growth to accelerate in 1976-78. If the defense is that failure to follow accommodating monetary policies would have raised unemployment, the reply has to be that the accommodation has resulted in both higher inflation and higher, though delayed, unemployment.

Finally, controls or incomes policies reflect policies of desperation. The economics are bad; the politics are bad; and the experience is bad. For example, The Wall Street Journal on May 9, 1980, reported that the administration is working on a new gasoline rationing plan estimated to cost $\$ 100$ million for planning and to have an annual operating cost of $\$ 2$ billion. Does any economist really want to put that kind of money into controls? Are advocates of "incomes policies" certain that the administrative complexities of their plans will not cost just as much, industry by industry, as this gasoline rationing plan? 


\section{General Discussion}

Responding to William Poole, Tobin argued that wage inertia is more than merely a descriptive term. The inflation process is, in fact, relatively unresponsive to changes in macro policy or real activity for reasons that are not simply expectational. Edmund Phelps' discussion of staggered contracts and Robert Hall's paper in this volume on long-term implicit contracts provide specific explanations for inertia.

Several participants discussed the limited role that productivity enhancement could be expected to play in slowing inflation. Martin Feldstein seconded Tobin's view that increases in productivity arising from faster capital formation would not make a major contribution to curing inflation. Not only was the productivity payoff likely to be very small, but the payoff in reducing inflation would be even smaller if part of any productivity enhancement went to labor as higher nominal wages. Feldstein voiced concern that policy might mistakenly rely on supply-side measures to cure inflation rather than relying on demand restraint.

The ability of monetary policy to affect the real rate of interest and investment was then discussed. In response to a question from Hendrik Houthakker, Tobin noted that, even in the long run, the real interest rate could be affected by monetary policy since higher inflation rates lowered the real return on noninterest-bearing financial assets such as money. Feldstein was more skeptical. He argued that real interest rates have been essentially unchanged over the past twenty years as inflation and nominal rates have risen together. But this has reduced the real after-tax cost of funds. It has encouraged home building and the purchase of consumer durables at the expense of business investment because the latter was discouraged by depreciation allowances for tax purposes that were inadequate in a period of inflation. Franco Modigliani objected that corporations also gain from being able to deduct the inflationary component of their interest payments as a cost, so that the effect of inflation on their 
investments is ambiguous. Patric Hendershott replied that, even if corporate investment is not adversely affected by inflation, it remained true that housing is particularly favored because the implicit income on housing services and nominal capital gains on housing are not taxed. Furthermore, removing these home ownership loopholes might be more difficult than Tobin had implied. Hendershott speculated that these loopholes might affect consumer saving: while the U.S. saving rate has declined precipitously in recent years, in Canada, where mortgage interest is not tax-deductible and the first thousand dollars of interest income is not taxed, saving rates have remained virtually constant since 1974 .

Houthakker argued that supply-side effects on inflation might be stronger than Tobin had allowed. He reported finding statistical evidence that increasing taxes increased prices. Furthermore, he believed taxes and income support programs both changed incentives to supply labor. Thus programs for redistributing income could have side effects that worked against their main purpose.

Benjamin Friedman interpreted Tobin's discussion of the macroeconomy as suggesting a system in which real fluctuations result primarily from policy fluctuations. Tobin appeared to suggest that, as the economy moves to high employment, inflation worsens and restrictive policies employed to fight inflation result in real downturns. As inflation has become an increasing problem, real disturbances associated with policy have come to dominate other sources of variation in real activity. Friedman noted the examples given by Tobin; he also cited earlier research by George Perry showing that policy had been contractionary in the period just preceding most postwar recessions, and noted that it is contributing to recession again in 1980 . He pointed out that this interpretation lent some support to the usual monetarist presumption that the economy is inherently stable in the absence of policy disturbances. Tobin responded that he was not offering a model of an economy that is stable in the absence of policy changes. Disturbances come from many sources, not just from policy, and are of many kinds. But he agreed with Friedman that the tendency of inflation to creep upward at high employment means policy is confronted with the choice of accommodating faster inflation or precipitating an economic downturn.

The role of expectations in policymaking to slow inflation was discussed by several participants. James Duesenberry accepted the description of policymakers alternating between accommodating inflation and 
trying to reduce it through demand restraint. But he questioned whether a determination this time to stay with restrictive policies would induce a much faster price deceleration by changing expectations. He therefore supported Tobin's proposal for some direct program to speed up deceleration as a supplement to any policy to restrict the growth of nominal demand. William Fellner noted that establishing the credibility of a determined restrictive policy was essential to its success, and conceded that this would take time because of the way in which policy had responded to recessions in the past at high levels of inflation. He suggested that if gradualist policies should fail, and an abrupt return to fully noninflationary demand management should become necessary, consideration should be given to the legislative adjustment of the nominal content of payment obligations accepted in the past to avoid badly distorting their intended real content. This would significantly reduce the shock of abrupt full disinflation in a world in which payment commitments reflect the expectation of continued inflation at an uncertain but appreciable rate.

Modigliani criticized rational expectations models that focus on expectations about money stock variables as too narrow. He remarked that target announcements about real income, nominal GNP, or other variables of direct policy concern would be more relevant to decisions in the private sector than announcements about intermediate variables such as monetary aggregates. Robert Gordon remarked that, while economists have been preoccupied with the propositions of Monetarism-2, those ideas have little practical effect on policymaking. Tobin disagreed, noting that the idea that inflation could be reduced without much cost simply by changing the policy environment was influential in current policy discussions.

Several participants discussed the effects that maintaining slack in the economy would have on the attainable rate of unemployment. William Branson pointed out that in the 1970s capacity utilization rates rose relative to unemployment rates in many countries. This suggested a change in capital-labor ratios that needed to be explained as a global rather than specifically a U.S. phenomenon. Martin Baily noted that maintaining slack in an economy should be expected to raise the natural rate of unemployment by discouraging capital formation, as Branson had reported, and also by eroding work skills. He cautioned, however, that experience did not reveal such effects: when the demands of war spending ended the Great Depression, unemployment declined rapidly and productivity re- 
turned to its previous path. On a lesser scale, employment and productivity both recovered fully after the extended slack period of 1957-61. William Nordhaus agreed with the caution in Tobin's paper that sociopolitical responses to high unemployment in the form of increased unemployment insurance, restrictive trade policies, adjustment assistance, and the like might increase the inflationary bias in the system. But he believed that once demand growth was restored, it would raise capacity utilization and induce the needed investment so that any potential imbalance between labor and capital at high employment would disappear. 